\title{
Does Microfinance Reduce Poverty in Bangladesh? New Evidence from Household Panel Data*
}

\author{
Katsushi S. Imai \\ Economics, School of Social Sciences, University of Manchester, UK \\ E-mail: Katsushi.Imai@manchester.ac.uk \\ \& \\ Md. Shafiul Azam \\ Economics, School of Social Sciences, University of Manchester, UK \\ E-mail: Md.Azam@postgrad.manchester.ac.uk
}

\begin{abstract}
The study examines whether loans from microfinance institutions (MFI) reduce poverty in Bangladesh drawing upon the nationally representative household panel with four rounds from 1997 to 2004. The effects of general microfinance loans and loans for productive purposes on income, food consumption and women's Body Mass Index are estimated. Overall effects of MFI loans on income and food consumption were positive and the purpose of the loan is important in predicting which household welfare indicator is improved. Alternative estimation methods confirm a positive impact of MFI loans on food consumption growth, which supports poverty reducing effects of microfinance in Bangladesh.
\end{abstract}

Key words: microfinance, MFI (microfinance institution), microcredit, poverty, Bangladesh

JEL codes: C30, C31, G21, I32

*Corresponding Author:

Katsushi Imai (Dr)

Economics, School of Social Sciences,

University of Manchester, Arthur Lewis Building,

Oxford Road, Manchester M13 9PL, UK

Phone: +44-(0)161-275-4827

Fax: +44-(0)161-275-4928

E-mail: Katsushi.Imai@manchester.ac.uk

\section{Acknowledgements}

We thank the managing editor, Oliver Morrissey, and two anonymous referees for useful comments that have greatly helped improve the paper. We also acknowledge comments and advice from Samuel Annim, Thankom Arun, Raghav Gaiha, Shoji Nishijima, Takahiro Sato, and seminar participants at Kobe University. Only the authors are responsible for any errors. 


\section{Does Microfinance Reduce Poverty in Bangladesh? New Evidence from Household Panel Data}

\section{Introduction}

The idea that microfinance helps poor people build businesses, increase their income and exit poverty has turned into a global movement, the so called 'microfinance revolution', in the fight against poverty over the last three decades. This is reflected in the significant increase of donor countries' investment in microfinance. The poor tend to have limited access to services from formal financial institutions in less developed countries due to, for example, (i) the lack of physical collateral; (ii) the cumbersome procedure to start transactions with formal banks, which would discourage those without education from approaching the banks; and (iii) lack of supply of credit in the rural areas related to urban biased banking networks and credit allocations. The hallmark of microfinance revolution is the system of group lending based on the joint liability or 'social capital' of groups which would guarantee to repay loans. ${ }^{1}$ Here the poor with no physical collateral are allowed to form a group to gain access to credit and the repayment rate is kept high because of, for example, mutual monitoring, sanction against non-repayment of the member or incentives to retain the individual reputation or credit within a community (e.g. Armendáriz and Morduch, 2005, Besley and Coate, 1995, Ahlin and Townsend, 2007).

The last thirty years witnessed a phenomenal growth in microfinance sectors serving about 40 million clients with an outstanding loan portfolio of US\$17 billion in mid-2006 and the projected market size could be around US\$250-300 billion in the near future (Ehrbeck, 2006). However, the argument that microfinance responds to the derived demand for borrowing to support self-employment and small business has come under intense scrutiny in recent years. Even the hard core of pro-microfinance researchers now broadly agree that attention should 
be drawn to both supply and demand sides of microfinance in order for the sector to have a noticeable poverty reducing effects. Micro-enterprises 'need a vibrant, well functioning domestic market itself that encompasses enough people with enough money to buy what these enterprises have to sell' (Pollin, 2007, p.2). Moreover, as noted by Bateman and Chang (2009), microfinance neglects the crucial role of scale economies and produces an oversupply of inefficient micro-enterprises that could undermine the development of more efficient small and medium industries (SMEs) that would be potentially able to reduce unit costs and register productivity growth in the long run. However, shifting donor funds away from very small groups or enterprises (target microfinance institutions) to SMEs could imply the neglect of the very poor who are credit constrained. The development agencies of donor countries or government will have to make sure that the benefits to programme participants are sustainable and large enough to make a dent in the poverty of participants and society at large.

Bangladesh has recorded a modest 4-6\% growth within a stable macroeconomic framework in recent years. Poverty has shown a consistent decline in incidence over time, especially in rural areas. However, aggregate poverty rates still remain dauntingly high. According to the estimates based on the Household Income and Expenditure Surveys (HIES) of the Bangladesh Bureau of Statistics, poverty head count ratio declined from $58.8 \%$ in 1991 to $48.9 \%$ per cent in 2000 and $40.0 \%$ in 2005 . So poverty has declined on average just above one percentage point a year since the 1990s. The observed improvement holds true for the distributionally sensitive poverty measures: the poverty gap ratio reduced from $17.2 \%$ to $12.9 \%$ and the squared poverty gap ratio from $6.8 \%$ to $4.6 \%$ from 2000 to 2005 . The situation of the poorest improved, but many very poor remain given inequality among the poor even in 2005. The rural head count ratio fell from $52.3 \%$ in 2000 to $43.8 \%$ in 2005 . However, the absolute number of people living below the poverty line rose, from 55 million in 2000 to 56 million people in 2005 . Similarly, hard core poverty remains almost the same 
(18.8\% and $18.7 \%$ in 2000 and 2005 respectively). So poverty reduction remains a daunting challenge for Bangladesh.

Bangladesh is credited with the largest and most vibrant microcredit sector in the world. Microcredit programmes are implemented in Bangladesh by a host of formal financial institutions, specialized government organizations and semi-formal financial institutions (nearly 1000 NGOs-MFIs). Furthermore, with a view to coordinating the flow of funds to appropriate use and NGO-MFI activities, the Palli Karma Sahayak Foundation (the Bengali acronym PKSF translated into English as "Rural Employment Support Foundation") came into being in 1990. The growth in the MFI sector, in terms of the number of MFIs as well as total membership, was phenomenal during the 1990s and after 2000. The effective coverage is around 17.32 million borrowers. The total amount is 24.25 million due to overlapping one borrower taking loans from more than one MFI and the extent of overlapping may be as high as $40 \%$ (PKSF, 2006). Out of 17.32 million borrowers covered by micro credit programmes, about $62 \%$ were below the poverty line, that is, 10.74 million poor borrowers were covered by MFI programmes. Out of estimated 56 million poor people in 2005, 29.26 million (53\%) were supposed to be economically active and potential target of microfinance operations. Therefore, there was still scope for further extending the coverage of microcredit programmes in 2005 to an approximate 18.52 million borrowers who were poor and economically active but not covered by MFI programmes (Ahmed, 2007).

The main purpose of the present study is to test whether microfinance reduces poverty in Bangladesh drawing upon a nationally representative household panel survey covering four rounds, 1997-98, 1998-99, 1999-2000, and 2004-05. Special attention is drawn to the issue of sample selection or endogeneity associated with participation in microfinance, by applying different household fixed effects models and difference in difference and propensity score 
matching (DID-PSM) ${ }^{2}$ to the sample of participants and non-participants of microfinance programmes.

The rest of the paper is organized as follows. The next section surveys the literature on poverty and microfinance in Bangladesh. Section III describes briefly the survey design and data. Section IV emphasises the underlying intuition of econometric models and Section V summarizes the econometric results and findings. The final section offers concluding observations.

\section{Literature on Poverty and Microfinance}

Despite the data limitations and methodological problems, e.g. in dealing with sample selection bias associated with microfinance participation or accounting for unobservable borrower characteristics, there are rigorous studies to assess the impact of microfinance on poverty. The findings of a set of studies summarised by Hulme and Mosley (1996) are somewhat provocative: households with initial higher income (above the poverty line) benefited from microfinance while poorer households (below the poverty line) did not. A majority of those with initial income below the poverty line actually ended up with less incremental income after obtaining microcredit, as compared to a control group which did not get any loans from MFI. Pitt and Khandker (1998) carried out a survey in 1991/92 involving about 1800 households in Bangladesh and found that for every 100 taka borrowed by a woman, household consumption expenditure increased by 18 taka. For a male borrower, the figure was 11 taka. They estimated the poverty reducing effect of three major microfinance institutions in Bangladesh - Bangladesh Rural Advancement Committee (BRAC), Grameen Bank, and Bangladesh Rural Development Board (BRDB). Moderate (ultra) poverty was reduced by about $15 \%(25 \%)$ for households who were BRAC members for up to three years. Similar results were found for Grameen Bank and BRDB members. ${ }^{3}$ 
Drawing upon the follow up survey in 1998/99, Khandker (2005) found strong results at both micro and aggregate levels: microcredit contributed to reducing poverty among poor borrowers and within the local economy. The impact appears to be greater for households who were initially extremely poor (18 percentage point drop in extreme poverty in seven years) compared to moderate poor households ( 8.5 percentage point drop). These results differ from earlier evidence that poorer borrowers benefit less because they face constraints in investing the loan in a high-return activity (Wood and Sharif, 1997). The finding that better off households benefit more was supported by case-study evidence (Farashuddin, and Amin, 1998) and by comparing participants of credit programmes that cater to different socioeconomic groups (Montgomery et al., 1996).

The general conclusions of Pitt and Khandker (1998) and Khandker (2005) are that microcredit was effective in reducing poverty, especially when borrowers were women, and the extremely poor benefited most in 1998/99. In contrast, Zaman (1998) suggests a threshold level of credit above which a household gains more in terms of increases in income. Microcredit appears to benefit the poor but evidence is miced on whether poorer or richer benefit more.

Using the same data as Pitt and Khandker (1998) and Morduch (1998) with propensity score matching (PSM) to identify treatment effects and account for endogenous programme placement, Chemin (2008) found that microfinance had a positive impact on participants' expenditure, supply of labour and male/female school enrolment. We extend Chemin (2008) in three ways. First, we use more recent and rich data for a panel of households in Bangladesh from 1997 to 2005 to examine the effects of microfinance participation on household welfare, in terms of log per capita household income, food consumption and women's body mass index (BMI). Second, while we also apply PSM to each cross-section component of the panel, we utilise the longitudinal nature of the data by applying different 
versions of a household fixed effects model and difference in difference (DID-PSM). Third, we consider if effects differ according to the purpose of loans from MFIs (whether for productive purposes or not). ${ }^{4}$

\section{Design of Survey and Data}

\section{(a) Details of Survey}

The four-round panel survey was carried out by the Bangladesh Institute of Development Studies (BIDS) for Bangladesh Rural Employment Support Foundation (PKSF) with funding from the World Bank. All four rounds of the survey were conducted during the DecemberFebruary period in 1997-98, 1998-99, 1999-2000, and 2004-05. The survey covered a sample of 13 PKSF Partner Organizations (PO) and over 3000 households in each round distributed evenly throughout Bangladesh so as to obtain a nationally representative data set for the evaluation of microfinance programmes in the country (different districts spanning 91 villages from around 23 thanas).

A sample of villages under each of the selected MFI was drawn through stratified random sampling. The stratification was based on the presence or absence of microfinance activities. The non-programme or control villages were selected from the neighbouring villages. At each PO, six to eight villages were selected depending on the availability of control villages. In selecting survey households, the universe of households in the programme villages drawn from the census was grouped according to their eligibility status. A household is said to be eligible if it owns 50 decimals (half an acre) or less of cultivable land. Participation status of the household is defined using the net borrowing from a MFI. If a household is not a participant in a given round, the net borrowing is zero for that household. From the village census list, 34 households were drawn from each of the programme and non-programme villages. The proportion of eligible and non-eligible households was kept at 
around 12:5 and the sample size within the programme and control villages was determined accordingly. The ratio is chosen to reflect the average participants to non-participants ratio of the population in the village. This is the largest and the most comprehensive data of its kind so far in Bangladesh collected with detailed information on a number of socio economic variables, including household demographics, consumption, assets and income, health and education and participation in microcredit programmes.

\section{(b) Descriptive Statistics and Definition of Variables}

The study uses two different definitions of access: first, whether a household is a client of any MFI and takes loans for general purposes or not, and second, whether a household has actually taken a loan from any MFI for productive purpose or not. The first definition is used to observe the effect of taking general loans from MFI on per capita household income, food consumption and women's $\mathrm{BMI}^{6}$ and thus on poverty. It is noted that unlike the first, third and fourth rounds, the second round consumption data are highly aggregated and not comparable with the other rounds. In case of BMI, comprehensive data are available only for the first and the last rounds, while the data on household income are available for all four rounds. The second is concerned with whether the household has taken loans for productive activities (and has an outstanding balance of loans at the time of survey) leading to an increase in production, for example, starting a small business or other self employment activities, like small scale poultry or cattle rearing. Loans used for consumption or other nonproductive activities like marriage or dowry are excluded from this category.

Online Appendix 1 provides the descriptive statistics of the variables for the sample households with access to loans from MFI and for those without. As shown by the number of observations, more than a half of the sample household have access to MFI loans. About a half of the borrowers have access to loans from MFI for productive purposes. In general, there is a relatively negligible difference between the descriptive statistics of each variable 
for the households with and without access to loans from MFIs (or with access to loans from MFIs for productive purposes) and for those without.

The average household size is about 6 for both categories of households. Heads of the households are categorised into four groups depending on their educational level - illiterate, completing primary education, secondary education, or higher education. Similarly, occupation of the head of the households is grouped into six distinct categories - farmers, agricultural wage labourers, non-agricultural wage labourers, small business, professionals (which comprises teachers, lawyers, doctors and other salaried employees), and others (beggars, students, retired persons, disabled, unemployed etc.). However, per capita income is generally higher for those who do not take MFI loan or participate in MFI programmes. This does not necessarily imply that taking loans from MFIs reduces per capita income due to the sample selection bias. About 93 per cent of the households are male headed, mainly due to the sample design where households in a village are selected randomly even though a majority of the MFI clients are female.

\section{Methodology}

To assess microfinance one would like to compare the impact on borrowers compared to similar non-borrowers, but such comparison is problematic for a number of reasons. First, MFIs are not distributed across regions or households randomly due to endogenous programme placement where MFIs generally target poorer households, or the core clientele for the services of MFIs are poorer households. Second, there is a self selection problem, that is, whether an individual participates in the MFI programme is determined by herself, not by chance. Where the MFI programme is available, individuals sharing similar socio-cultural backgrounds (e.g., education, age or religion) might have different levels of entrepreneurial skills and latent ability leading to different probabilities to their participating in a certain 
programme. Hence, it is essential to take into account the endogeneity or self-selection problems in assessing the impact of microfinance. Alternative estimators are employed to address these issues.

\section{(1) Panel Data Model}

\section{Fixed Effects (FE) Model}

First, we apply different versions of a household fixed effects model to take into account the amount of MFI general or productive loans (PSM or DID-PSM can consider only binary classification of participation status). The standard fixed effect model is estimated as:

$$
W_{i t}=\beta_{0}+X_{i t} \beta_{1}+L_{i t} \beta_{2}+Y_{t} \beta_{3}+\mu_{i}+\varepsilon_{i t}
$$

where $W_{i t}$ is the outcome variable (namely, log household income per capita, log food consumption per capita or women's BMI), $X_{i t}$ is a vector of variables of household and socio-economic characteristics as well as other control variables, and $L_{i t}$ is either a total amount of MFI loans or a vector consisting of MFI productive and non-productive loans (the sum is equal to the total amount of MFI loans). We are interested in the sign of coefficient on $L_{i t}, \beta_{2}$ which represents the effects of MFI loan on the outcome variable. ${ }^{7} Y_{t}$ is a vector of year dummies to take account of time specific effects, $\mu_{i}$ is a household-specific unobservable fixed effect (e.g. unobserved entrepreneurship), and $\varepsilon_{i t}$ is an error term, i.i.d. (see, e.g. Greene, 2003). For the income equation, we use household characteristics $\left(X_{i t}\right)$, such as arable land and its square, age of the household head and its square, household size, sex of the household head, education of the head, occupational categories, and whether a household has access to electricity. For the equations for food consumption and BMI, we replace arable land and its square by a set of prices (for rice, potatoes and milk). 
Fixed Effects Model with PSM (FE-PSM)

Initial household characteristics as well as pre-existing socio-economic and area attributes are likely to influence the programme placement and the subsequent growth paths of outcome variables. Controlling for these potential sources of selection bias would bring us a more credible estimate of the policy effect. To deal with these sources of bias, we need to control for the initial conditions as well as time-varying factors that would influence the programme placement and growth rates. One possible way of correcting for these biases is to use PSM to select appropriate counterfactuals from the sampled non-participants (Ravallion and Chen, 2005, Chen et al., 2008). Matching methods or PSM will construct the control groups that are as similar as possible except for the access to microfinance programmes. PSM will trim the sample of control group with propensity scores that do not overlap with those for the treatment groups. More specifically, we carry out PSM for each round and match the continuous participants for four rounds with non-participating ones in each round. ${ }^{8}$ Second, we drop all the households which are not matched, or outside the common support region. ${ }^{9}$ In order to control for the initial conditions and any time-varying factors, we have carried out the fixed-effects model for the reconstructed panel data in which participating households have been matched with controls.

\section{Fixed Effects (FE) Model with control for initial characteristics}

In the FE or FE-PSM estimation, some of the explanatory variables have either a linear time trend or little variation over time and they are swept away in the process of first-differencing. However, these variables may have a significant effect on the change in outcome variables and eliminating them from the model might bias the policy effect. To circumvent this problem, using only the data of the first and last rounds, we implement an alternate version of the fixed effects model where initial characteristics of households (e.g. age of household head 
and its square; household size; sex of head of the household; education; occupation; access to electricity) are used along with the first differenced variables. The purpose of these models is also to correct any possible bias due to pre-existing initial heterogeneity of households and time-varying factors.

\section{(2) DID-PSM}

There is a huge empirical literature where the policy effects are estimated by PSM. The method is applied, in many cases, to cross-sectional data because of the limitations of IV models (e.g. assuming linearity; requiring a valid instrument; sensitivity of the results to specifications). PSM matches a participating household in MFIs with a non-participating household by using the propensity score, the estimated probability of participating in the microfinance programmes. We can then obtain average treatment effect (ATT) of the policy by comparing the averages of outcome variables for participants and non-participants. In PSM, the first stage specifies a function matching the proximity of one household to another in terms of household characteristics and then households are grouped to minimize the distance between matched cases in the second stage (Foster, 2003). Rosenbaum and Rubin (1983) proposed statistical matching using the propensity score, the predicted probability that an individual receives the treatment of interest to make comparisons between individuals with the treatment and those without. Models and methodological issues for propensity score matching estimation are discussed in, for example, Becker and Ichino (2002), Dehejia (2005), Dehejia and Wahba (2002), Heckman et al. (1997), Ravallion (2008), Smith and Todd (2005), and Todd (2008). ${ }^{10}$ In the first stage logit model of PSM, we include the same set of explanatory variables which we use for the panel data model as well as (i) number of village money lenders and (ii) distance from nearest 'Upzilla', the business and administrative hub where most of the local services including marketing and financial are available. 
While there are some advantages in using PSM to estimate the impact of policy, the derived impact depends on the variables used for matching and the quantity and quality of available data and the procedure to eliminate any sample selection bias based on observables (Ravallion, 2008). If there are important unobservable variables in the model, the bias is still likely to remain in the estimates. For example, if the selection bias based on unobservables counteracts that based on observables, then eliminating only the latter bias may increase aggregate bias. The replication studies comparing non-experimental evaluations, such as PSM, with experiments for the same programmes do not appear to have found such an example in practice (Heckman et al., 1997, Ravallion, 2008). However, there may be systematic differences between participants and non-participant outcomes even after conditioning on household's observable characteristics, which could lead to the violation of the identification condition required for PSM (Smith and Todd, 2005). Because bias cannot be completely eliminated if there are important unobservable variables in the model, the results of PSM for cross-sectional data will have to be interpreted with caution. Therefore, the present study reports the PSM results in Online Appendix 3 and provide only a summary of the results.

To overcome the limitations of PSM using cross-sectional data, we apply the DID-PSM method which utilises the longitudinal nature of the data. The DID-PSM estimator requires, as specified by (Smith and Todd, 2005):

$$
E\left(W_{0 i}^{t}-W_{0 i}^{t^{\prime}} \mid p_{i}\left(X_{i}\right), D_{i}=1\right)=E\left(W_{0 i}^{t}-W_{0 i}^{t^{\prime}} \mid p_{i}\left(X_{i}\right), D_{i}=0\right)
$$

where $t$ and $t^{\prime}$ are time periods (where $t=1$ and $t^{\prime}=0$, or after and before the programme). $W_{0 i}^{t}$ is the outcome at time $t$ for non-participant, $p_{i}\left(X_{i}\right)$ is a propensity score, the probability of participation at time $t$, and $D_{i}$ is whether a household participated in a microfinance programme between $t^{\prime}$ and $t$ ( 1 if participated, 0 otherwise). In the PSM applied to the cross- 
section data, the mean of the outcome of a household at a particular point of time is compared between participants and non-participants conditional on the probability of participation estimated by observable household characteristics, whilst in the DID-PSM, the time-series or temporal change of outcome of a household is compared at time $t$ (after the programme) conditional on the propensity score. The results of the latter are not subject to the existence of unobservable household characteristics in the model. In our context, DID-PSM implies that PSM is applied to 'the first difference' (from $t$ 'to $t$ ) of the outcome variable (e.g. log per capita income) of a household with access to MFI loans at $t$, but not at $t^{\prime}$, the previous round, is compared with that of a household with the same characteristics (with respect to the propensity score), but without any access to MFI loans at both $t^{\prime}$ and $t$, along the lines of Smith and Todd (2005).

\section{Results}

\section{(1) Results of Fixed-effects models}

Tables $1 \mathrm{a}, 1 \mathrm{~b}$, and $1 \mathrm{c}$ report the results of different versions of fixed effects models where we estimate either the effect of MFI general (total), productive and non-productive loans on log household income per capita, log food consumption per capita, and BMI of a female member.

\section{(Tables 1a, 1b and 1c to be inserted around here)}

The results of the simple fixed effects model show that MFI general loans tend to significantly increase household income (column 1 of Table 1a). If MFI loan is disaggregated into the productive component and the non-productive component (column 4), it is found that the positive effect of the total loan is associated only with the productive component. In fact, the non-productive component tends to reduce household income per capita. We obtain similar results for the fixed effects model with PSM and with control for initial characteristics 
(columns 2, 3, 5 and 6). That is, results are robust to use of alternative models in which initial household characteristics are taken into account. However, the magnitude of these effects is not so large - even $100 \%$ increase in loan size raises household income per capita only by $0.51 \%$ to $0.54 \%$ on average ceteris paribus. However, $100 \%$ increase in loan size raises household income per capita by $0.69 \%$ to $1.09 \%$ on average ceteris paribus.

The non-productive component is positive and significant and the productive component is non-significant in the case where food consumption is estimated in Table $1 \mathrm{~b}$ (columns 7 and 10). The results are once again similar in the cases where alternative versions of fixedeffects model are used (columns 8, 9, 11 and 12). MFI general loan has a significant and positive effect on food consumption; a $100 \%$ increase in total loan raises household food consumption per capita by $0.52 \%$ to $1.02 \%$ on average ceteris paribus. On the other hand, $100 \%$ increase in non-productive loan increases household food consumption per capita by $0.74 \%$ to $1.11 \%$ on average ceteris paribus.

While the aggregate component of MFI loans is not a significant determinant of women's BMI in any version of fixed-effects models (columns 13, 14 and 15, Table 1c), nonproductive loans show a significant and positive effect on women's BMI as in the case of food consumption (columns 16, 17 and 18). The absolute impact seems substantial as, for example, $10 \%$ increase in non-productive loans raises women's BMI by 0.44 point in columns 16 and 17, while it is only 0.017 in column 18 where initial household characteristics are included in the model. The results are different from those of DID-PSM to be discussed in the next sub-section, but it is conjectured that having access to a larger amount of the non-productive component of MFI loans, rather than simply accessing MFI loans, is important in raising BMI for women.

\section{(2) Results of DID-PSM ${ }^{11}$}


The results of logit model (the first stage of DID-PSM) show the determinants of access to MFI general loans or loans for productive purposes. A full set of the results as well as explanations are provided in Online Appendix 2. Table 2 presents the final results of DIDPSM. It is noted that after controlling for the propensity score, DID-PSM compares the first differences of, e.g., log income for the households which accesses MFI loans in the present round but did not in the previous round, and those which have never accessed MFI loans. Because the objective variable is in log term, the policy (or average treatment) effect denotes the growth of household income per capita (or food consumption/ women's BMI) achieved by accessing general (or productive) loans. While DID-PSM is superior to PSM in correcting for sample selection biases, because of the relatively small sample size of treatment groups in our context, the estimated average treatment effect tends to be generally insignificant. Case (a) is where DID-PSM is applied to see if household access to MFI general loans increases the growth of household income per capita, food consumption, and women's BMI. Only a significant policy effect is observed for food consumption per capita growth from 1999-2000 to 2004-5. That is, a household which had access to MFI loans in 2004-5, but not in 19992000 had 10.4\% higher per capita food consumption growth on average than the household with the same characteristics (in terms of propensity score) which did not access MFI loans in either of these years. It is noted that the former (new participants in 2004-5) did not see increase in their household income in 2004-5. Case (b) considers household access to MFI productive loans, but the policy effects are insignificant.

\section{(Table 2 to be inserted around here)}

Though the average treatment effects are statistically insignificant except one case in Table 2 and the effects of loans on household income growth appears negative in the last period (1999-2000 to 2004-5), the effects on food consumption remained positive in the last 
period. To see why, we have disaggregated DID-PSM by four income groups, that is, $0-25 \%$, $25-50 \%, 50-75 \%$ and $75-100 \%$ of household per capita income of the first round. First, the average treatment effects of general loan on food consumption growth of relatively poor income groups (0-25\% and 25-50\%) are consistently positive (with the effects statistically significant for the $25-50 \%$ group for both '1997-8 to 1999-2000' and '1999-2000 to 2004-5'), while the effects on relatively richer income groups (50-75\% and $75-100 \%)$ become negative and insignificant for 1999-2000 to 2004-5. That is, the effect of MFI loans in increasing food consumption growth was strong for poorer groups, confirming the poverty-reducing role of MFI general loan. Second, the effects of MFI general loans on household income are insignificant for most of the groups for all the cases (four periods) except one case where the loans had a significant and negative average impact on income growth of the 50-75\% group for $1999-2000$ to $2004-5$.

\section{Concluding Observations}

The main purpose of the present study is to examine whether microfinance reduced poverty defined in terms of household income, food consumption and women's BMI - in Bangladesh drawing upon the nationally representative household panel data covering four rounds, 199798, 1998-99, 1999-2000, and 2004-05. Special attention was given to the issue of endogeneity by applying different versions of fixed effects model as well as DID-PSM proposed by Smith and Todd (2005), following a recent contribution by Chemin (2008). Another contribution of the present study is that it distinguishes between the effects of different purposes of loans from microfinance institutions (MFIs) on household income, i.e., whether loans were used for the purposes of enhancing agricultural productivity or for general purposes, such as consumption. 
We applied household fixed-effects models with and without control for initial household characteristics to the panel data in order to estimate the effects of amount of aggregate, productive and non-productive loans. A positive and significant effect of the aggregate component of MFI loans is found for both household income and food consumption, but this is due to the positive effect of the productive component for income, and the non-productive component for food consumption. That is, income poverty tends to be alleviated by offering productive loans for households and consumption poverty is likely to be reduced by nonproductive loans. It is also found that MFI non-productive loans will reduce BMI. These results are broadly consistent with the past studies which have confirmed poverty reducing effects of microfinance programmes in Bangladesh (e.g. Pitt and Khandker, 1998, Khandker, 2005 and Chemin, 2008). DID-PSM confirms that the households which accessed MFI's general loans in 2004-05, but not in 1999-2000, had a higher food consumption growth than those which did not access to microfinance loans in either of these years.

Whether microfinance actually reduced poverty in Bangladesh has been a highly controversial issue among both academics and policy makers. It can be concluded by our results based on new household panel data that loans provided by microfinance institutions had significant poverty reducing effects particularly on income and consumption in Bangladesh, which is consistent with some of earlier studies using household data in the 1990s, for example, Pitt and Khandker (1998), Khandker (2005), and Chemin (2008). We did not find much evidence to support the critique of microfinance as an effective measure of poverty alleviation, such as, Morduch (1998) and Roodman and Morduch (2009). In contrast to earlier works, our study has also implied that purposes of loans - whether they are used for productive or non-productive purposes - are important for predicting poverty-reducing outcomes of MFI loans and that tracking the effects of microfinance over the long period is crucial in impact evaluations. 
Table 1a Panel Data Models for Income

\begin{tabular}{|c|c|c|c|c|c|c|}
\hline & (1) & (2) & (3) & (4) & (5) & (6) \\
\hline Dependent Variable & & $\log h$ & usehold $\mathbf{i}$ & come pe & capita & \\
\hline $\begin{array}{l}\text { Model Chosen } \\
\text { Explanatory Variables }\end{array}$ & $\begin{array}{l}\text { Fixed- } \\
\text { Effects }\end{array}$ & $\begin{array}{l}\text { Fixed- } \\
\text { Effects } \\
\text { with } \\
\text { PSM }\end{array}$ & $\begin{array}{c}\text { Fixed- } \\
\text { Effects } \\
\text { :Control } \\
\text { for initial } \\
\text { Character- } \\
\text { istics }\end{array}$ & $\begin{array}{l}\text { Fixed- } \\
\text { Effects }\end{array}$ & $\begin{array}{l}\text { Fixed- } \\
\text { Effects } \\
\text { with } \\
\text { PSM }\end{array}$ & $\begin{array}{c}\text { Fixed- } \\
\text { Effects } \\
\text { :Control } \\
\text { for initial } \\
\text { Character- } \\
\text { istics }\end{array}$ \\
\hline MFI loan amount (aggregate) & $0.0051^{* 1}$ & $0.0054^{\star}$ & 0.0054 & - & - & - \\
\hline$(\log )$ & $(2.37)$ & $(2.46)$ & $(1.59)$ & - & - & - \\
\hline MFI's productive loan amount & - & - & - & $0.0069^{\star \star}$ & $0.0072^{\star \star}$ & $0.0109^{\star \star}$ \\
\hline$(\log )$ & - & - & - & (3.22) & $(3.30)$ & (3.08) \\
\hline MFI's non-productive loan amount & - & - & - & $-0.0054^{\star}$ & $-0.0053^{\star}$ & $-0.0079+$ \\
\hline$(\log )$ & - & - & - & $(-2.22)$ & $(-2.17)$ & $(-1.78)$ \\
\hline Arable land area & 0.318 & 0.284 & $0.021^{*}$ & 0.321 & 0.284 & 0.0207 \\
\hline$(\log )$ & $(0.90)$ & $(0.80)$ & $(1.66)$ & $(0.91)$ & $(0.80)$ & $(1.61)$ \\
\hline Initial Arable land area & - & - & 0.704 & - & - & 0.683 \\
\hline$(\log )$ & - & - & $(0.95)$ & - & - & $(0.92)$ \\
\hline Arable land area $^{2}$ & -0.152 & -0.135 & - & -0.153 & -0.135 & - \\
\hline$(\log )$ & $(-0.86)$ & $(-0.75)$ & - & $(-0.86)$ & $(-0.76)$ & - \\
\hline Initial Arable land area ${ }^{2}$ & - & - & -0.360 & - & - & -0.350 \\
\hline$(\log )$ & - & - & $(-0.97)$ & - & - & $(-0.94)$ \\
\hline Age of the head of the hh & 0.00146 & 0.0010 & 0.0015 & 0.00145 & 0.0010 & 0.0014 \\
\hline & $(0.86)$ & $(0.58)$ & $(0.56)$ & $(0.86)$ & $(0.58)$ & $(0.52)$ \\
\hline Initial Age of the head of the hh & - & - & $0.023^{*}$ & - & - & 0.024 \\
\hline & - & - & $(2.43)$ & - & - & $(2.51)$ \\
\hline Age_squared & & $-4.71 \mathrm{e}-$ & $-6.02 e-06$ & & $-4.71 e-06$ & \\
\hline & $\begin{array}{c}-5.54 \mathrm{e}-06 \\
(-1.13)\end{array}$ & $\begin{array}{c}06 \\
(0.95)\end{array}$ & $(0.87)$ & $\begin{array}{c}-5.58 \mathrm{e}-06 \\
(-1.14)\end{array}$ & $(0.96)$ & $\begin{array}{c}-5.69 \mathrm{e}-06 \\
(-0.82)\end{array}$ \\
\hline Initial Age_squared & - & - & $-0.0002^{*}$ & - & - & -0.0002 \\
\hline & - & - & $(-2.02)$ & - & - & $(2.10)$ \\
\hline Household size & $-0.025^{\star \star}$ & $-0.024^{\star *}$ & $-0.037^{\star \star}$ & $-0.0251^{\star *}$ & $-0.024^{\star *}$ & $-0.037^{\star *}$ \\
\hline & $(-4.73)$ & $(-4.56)$ & $(-5.30)$ & $(-4.75)$ & $(-4.59)$ & $(-5.34)$ \\
\hline Initial Household size & - & - & $0.059^{* *}$ & - & - & 0.059 \\
\hline & - & - & $(6.28)$ & - & - & $(6.34)^{\star *}$ \\
\hline Sex of head of household & $-0.308^{\star \star}$ & $-0.301^{* *}$ & $-0.348^{* *}$ & $-0.313^{* *}$ & $-0.306^{\star *}$ & $-0.357^{\star *}$ \\
\hline (female or not) & $(-5.17)$ & $(-5.01)$ & $(-4.30)$ & $(-5.25)$ & $(-5.09)$ & $(-4.42)$ \\
\hline Initial Sex of head of household & - & - & 0.059 & - & - & $-0.260^{\star *}$ \\
\hline & - & - & $(6.28)^{\star \star}$ & - & - & $(2.56)^{* \star}$ \\
\hline Education of head of household & 0.0622 & 0.062 & 0.067 & 0.0611 & 0.061 & 0.069 \\
\hline - completed primary school & $(1.57)$ & $(1.53)$ & $(1.98)^{*}$ & $(1.54)$ & $(1.50)$ & $(2.05)^{\star}$ \\
\hline Education of head of household & 0.0834 & 0.0771 & - & 0.0816 & 0.0753 & - \\
\hline - completed secondary school & $(1.59)$ & $(1.43)$ & - & $(1.56)$ & $(1.40)$ & - \\
\hline Education of head of household & -0.0684 & -0.063 & - & -0.0666 & -0.062 & - \\
\hline - completed higher education & $(-0.64)$ & $(-0.58)$ & - & $(-0.62)$ & $(-0.57)$ & - \\
\hline Initial education of head & -10.04 & - & 0.030 & $\begin{array}{c}(-0.0<) \\
-\end{array}$ & - & 0.033 \\
\hline - completed primary school & - & - & $(0.56)$ & - & - & $(0.61)$ \\
\hline Initial education of head & - & - & $0.121^{*}$ & - & - & $0.117^{*}$ \\
\hline - completed secondary school & - & - & $(2.15)$ & - & - & $(2.10)$ \\
\hline Initial Education of head & - & - & 0.431 & - & 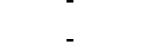 & 0.420 \\
\hline - completed higher education & - & - & $(3.49)^{\star *}$ & - & - & $(3.41)^{* *}$ \\
\hline Farmer & $-0.228^{\star \star}$ & $-0.245^{\star *}$ & 0.011 & $-0.225^{\star *}$ & $-0.243^{\star *}$ & 0.012 \\
\hline & $(-3.93)$ & $(-4.18)$ & $(1.21)$ & $(-3.89)$ & $(-4.14)$ & $(1.31)$ \\
\hline Agricultural wage labourer & $-0.110+$ & $-0.132^{*}$ & - & -0.105 & $-0.136+$ & - \\
\hline & $(-1.68)$ & $(1.98)$ & - & $(-1.60)$ & $(1.90)$ & - \\
\hline Non-Agricultural wage labourer & $-0.125^{\star}$ & $-0.141^{*}$ & - & $-0.121^{*}$ & $-0.136^{*}$ & - \\
\hline & $(-2.08)$ & $(-2.32)$ & - & $(-2.01)$ & $(-2.25)$ & - \\
\hline small business & 0.00533 & -0.010 & - & 0.00744 & -0.008 & - \\
\hline & $(0.09)$ & $(-0.18)$ & - & $(0.13)$ & $(-0.14)$ & - \\
\hline professionals & -0.0572 & -0.068 & - & -0.0526 & -0.063 & - \\
\hline
\end{tabular}




\begin{tabular}{|c|c|c|c|c|c|c|}
\hline \multirow{3}{*}{ others } & $(-0.87)$ & $(1.02)$ & - & $(-0.80)$ & $(0.95)$ & - \\
\hline & $-0.146^{*}$ & $-0.161^{* *}$ & - & $-0.141^{*}$ & $-0.156^{\star *}$ & - \\
\hline & $(-2.57)$ & $(-2.80)$ & - & $(-2.49)$ & $(-2.71)$ & - \\
\hline \multirow[t]{2}{*}{ Farmer (Initial) } & - & - & 0.063 & - & - & 0.066 \\
\hline & - & - & $(0.83)$ & - & - & $(0.86)$ \\
\hline \multirow[t]{2}{*}{ Agricultural wage labourer (Initial) } & - & - & -0.062 & - & - & -0.066 \\
\hline & - & - & $(0.77)$ & - & - & $(0.81)$ \\
\hline \multirow{4}{*}{$\begin{array}{l}\text { Non-Agricultural wage labourer } \\
\text { (Initial) } \\
\text { small business (Initial) }\end{array}$} & - & - & - & - & - & - \\
\hline & - & - & - & - & - & - \\
\hline & - & - & $-0.219^{* *}$ & - & - & $-0.208^{* *}$ \\
\hline & - & - & $(2.94)$ & - & - & $(2.80)$ \\
\hline \multirow[t]{2}{*}{ Professionals (Initial) } & - & - & -0.091 & - & - & -0.095 \\
\hline & - & - & $(0.92)$ & - & - & $(0.96)$ \\
\hline \multirow[t]{2}{*}{ Others (Initial) } & - & - & 0.063 & - & - & 0.063 \\
\hline & - & - & $(0.65)$ & - & - & $(0.65)$ \\
\hline \multirow[t]{2}{*}{ Whether a household } & & $0.0845^{\star}$ & 0.0731 & & $0.0854^{* *}$ & 0.0703 \\
\hline & $0.0830^{* *}$ & ${ }^{*}{ }^{*}$ & & $0.0840^{* *}$ & & (1 57) \\
\hline \multirow{2}{*}{$\begin{array}{l}\text { Whether a household } \\
\text { has electricity or not (Initial) }\end{array}$} & $\begin{array}{c}(3.12) \\
-\end{array}$ & $(3.15)$ & $\begin{array}{l}(1.63) \\
0.006\end{array}$ & $\begin{array}{c}(3.16) \\
-\end{array}$ & $(3.18)$ & $\begin{array}{l}(1.57) \\
0.009\end{array}$ \\
\hline & - & - & $(0.12)$ & - & - & $(0.17)$ \\
\hline price of rice & - & - & - & - & - & - \\
\hline$(\log )$ & - & - & - & - & - & - \\
\hline price of potatoes & - & - & - & - & - & - \\
\hline$(\log )$ & - & - & - & - & - & - \\
\hline price of milk & - & - & - & - & - & - \\
\hline$(\log )$ & - & $0.0899^{*}$ & - & - & - & - \\
\hline \multirow[t]{2}{*}{ Whether in 1998-9 } & $0.0936^{\star *}$ & * & - & $0.102^{\star *}$ & $0.0985^{\star \star}$ & - \\
\hline & $(5.35)$ & $(5.09)$ & - & $(5.77)$ & $(5.50)$ & - \\
\hline \multirow[t]{2}{*}{ Whether in1999-2000 } & $0.189^{* *}$ & $0.190^{* *}$ & - & $0.195^{\star *}$ & $0.195^{\star *}$ & - \\
\hline & $(10.44)$ & $(10.36)$ & - & $(10.70)$ & $(10.61)$ & - \\
\hline \multirow[t]{2}{*}{ Whether in 2004-5 } & $0.446^{\star *}$ & $0.443^{* *}$ & - & $0.451^{\star \star}$ & $0.449^{* *}$ & - \\
\hline & (19.06) & $(18.67)$ & - & $(19.24)$ & $(18.85)$ & - \\
\hline \multirow[t]{2}{*}{ Constant } & 6.445 & 6.471 & 0.176 & $6.449^{\star \star}$ & 6.475 & -0.192 \\
\hline & (59.59) & $(58.66)$ & $(0.73)$ & $(59.72)$ & $(58.78)$ & $(0.80)$ \\
\hline \multirow{4}{*}{$\begin{array}{l}\text { Observations } \\
\text { Number of hhid } \\
\text { Joint Significance }\end{array}$} & 10,388 & 10,076 & 2,484 & 10,388 & 10,388 & 2,484 \\
\hline & 2,669 & 2545 & 1,242 & 2,669 & 2,545 & 1,242 \\
\hline & $F(20,7699)$ & $F(20,7511)$ & $F(24,2459)$ & $F(21,7698)$ & $F(21,7510)$ & $F(25,2458)$ \\
\hline & $39.46^{\star \star}$ & $38.52^{\star \star}$ & $7.71^{\star \star}$ & $38.01^{\star *}$ & $37.11^{\star \star}$ & $7.79^{\star \star}$ \\
\hline
\end{tabular}

Table 1b Panel Data Models for Food Consumption

\begin{tabular}{|c|c|c|c|c|c|c|}
\hline \multirow[b]{2}{*}{$\begin{array}{l}\text { Model Chosen } \\
\text { Explanatory Variables }\end{array}$} & (7) & $(8)$ & $\begin{array}{l}\text { (9) } \\
\text { (9) }\end{array}$ & $\begin{array}{c}(10) \\
n\end{array}$ & (11) & (12) \\
\hline & $\begin{array}{l}\text { Fixed- } \\
\text { Effects }\end{array}$ & \begin{tabular}{l}
\multicolumn{1}{l}{$\log$ I } \\
Fixed- \\
Effects \\
with \\
PSM
\end{tabular} & $\begin{array}{l}\text { Fixed- } \\
\text { Effects } \\
\text { :Control } \\
\text { for initial } \\
\text { Character- } \\
\text { istics }\end{array}$ & $\begin{array}{l}\text { nption p } \\
\text { Fixed- } \\
\text { Effects }\end{array}$ & $\begin{array}{l}\text { caplta } \\
\text { Fixed- } \\
\text { Effects } \\
\text { with } \\
\text { PSM }\end{array}$ & $\begin{array}{c}\text { Fixed- } \\
\text { Effects } \\
\text { :Control } \\
\text { for initial } \\
\text { Character- } \\
\text { istics }\end{array}$ \\
\hline $\begin{array}{l}\text { MFI loan amount (aggregate) } \\
\text { (log) }\end{array}$ & $\begin{array}{c}0.0052+{ }^{1} \\
(1.88)\end{array}$ & $\begin{array}{c}0.0048+ \\
(1.70)\end{array}$ & $\begin{array}{l}0.0102^{\star \star} \\
(2.77)^{\star \star}\end{array}$ & $\begin{array}{l}- \\
-\end{array}$ & $\begin{array}{l}- \\
-\end{array}$ & $\begin{array}{l}- \\
-\end{array}$ \\
\hline $\begin{array}{l}\text { MFI's productive loan amount } \\
\text { (log) }\end{array}$ & $\begin{array}{l}- \\
-\end{array}$ & $\begin{array}{l}- \\
-\end{array}$ & $\begin{array}{l}- \\
-\end{array}$ & $\begin{array}{c}0.00213 \\
(0.77)\end{array}$ & $\begin{array}{c}0.00177 \\
(0.63)\end{array}$ & $\begin{array}{c}0.00053 \\
(0.01)\end{array}$ \\
\hline $\begin{array}{l}\text { MFI's non-productive loan amount } \\
\text { (log) }\end{array}$ & - & $\begin{array}{l}- \\
-\end{array}$ & $\begin{array}{l}- \\
-\end{array}$ & $\begin{array}{c}0.00747^{\star} \\
(2.24)\end{array}$ & $\begin{array}{c}0.00742^{\star} \\
(2.21)\end{array}$ & $\begin{array}{c}0.0111^{*} \\
(2.35)\end{array}$ \\
\hline Arable land area & - & - & - & - & - & - \\
\hline $\begin{array}{l}\text { (log) } \\
\text { Initial Arable land area }\end{array}$ & - & $\begin{array}{l}- \\
-\end{array}$ & $\begin{array}{l}- \\
-\end{array}$ & $\begin{array}{l}- \\
-\end{array}$ & $\begin{array}{l}- \\
-\end{array}$ & $\begin{array}{l}- \\
-\end{array}$ \\
\hline$(\log )$ & - & - & - & - & - & - \\
\hline Arable land area $^{2}$ & - & - & - & - & - & - \\
\hline 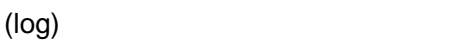 & - & - & - & - & - & - \\
\hline
\end{tabular}




\begin{tabular}{|c|c|c|c|c|c|c|}
\hline \multirow{2}{*}{$\begin{array}{l}\text { Initial Arable land area } \\
(\log )\end{array}$} & - & - & - & - & - & - \\
\hline & - & - & - & - & - & - \\
\hline Age of the head of the hh & $\begin{array}{c}-0.00217 \\
(-1.10)\end{array}$ & $\begin{array}{c}-0.00154 \\
(-0.76)\end{array}$ & $\begin{array}{c}-0.00081 \\
(-0.28)\end{array}$ & $\begin{array}{c}-0.00222 \\
(-1.12)\end{array}$ & $\begin{array}{c}-0.00159 \\
(-0.78)\end{array}$ & $\begin{array}{c}-0.00083 \\
(-0.29)\end{array}$ \\
\hline Initial Age of the head of the hh & $\begin{array}{l}- \\
-\end{array}$ & - & $\begin{array}{c}0.0079 \\
(0.78)\end{array}$ & & & $\begin{array}{c}0.0073 \\
(0.78)\end{array}$ \\
\hline Age_squared & $\begin{array}{c}2.05 \mathrm{e}-07 \\
(0.036)\end{array}$ & $\begin{array}{c}-9.44 \mathrm{e}- \\
07 \\
(-0.17)\end{array}$ & $\begin{array}{c}-1.79 \mathrm{e}-06 \\
(-0.25)\end{array}$ & $\begin{array}{l}3.71 \mathrm{e}-07 \\
(0.07)\end{array}$ & $\begin{array}{l}-7.75 \mathrm{e}- \\
07 \\
(0.14)\end{array}$ & $\begin{array}{c}-1.26-06 \\
(-0.17)\end{array}$ \\
\hline Initial Age_squared & $\begin{array}{l}- \\
-\end{array}$ & $\begin{array}{l}- \\
-\end{array}$ & $\begin{array}{r}-0.0001 \\
(-1.07)\end{array}$ & & & $\begin{array}{r}-0.0001 \\
(-0.99)\end{array}$ \\
\hline Household size & $\begin{array}{l}0.0504^{* *} \\
(8.79)\end{array}$ & $\begin{array}{c}0.0501^{\star *} \\
(8.66)\end{array}$ & $\begin{array}{c}0.0336^{\star *} \\
(4.54)\end{array}$ & $\begin{array}{c}0.0505^{\star \star} \\
(8.82)\end{array}$ & $\begin{array}{l}0.0503^{\star *} \\
(8.69)\end{array}$ & $\begin{array}{c}0.0350 * * \\
(4.73)\end{array}$ \\
\hline Initial Household size & - & $\begin{array}{ll}- \\
-\end{array}$ & $\begin{array}{l}0.1753^{* *} \\
(17.36)\end{array}$ & & & $\begin{array}{c}0.1738^{* *} \\
(17.18)\end{array}$ \\
\hline $\begin{array}{l}\text { Sex of head of household } \\
\text { (female or not) }\end{array}$ & $\begin{array}{c}0.00629 \\
(0.092)\end{array}$ & $\begin{array}{c}0.00829 \\
(0.12)\end{array}$ & $\begin{array}{l}0.0619 \\
(0.74)\end{array}$ & $\begin{array}{l}0.0120 \\
(0.18)\end{array}$ & $\begin{array}{l}-0.0023 \\
(-0.03)\end{array}$ & $\begin{array}{l}0.0679 \\
(0.81)\end{array}$ \\
\hline Initial Sex of head of household & $\begin{array}{l}- \\
-\end{array}$ & $\begin{array}{l}- \\
-\end{array}$ & $\begin{array}{l}0.009 \\
(0.08)\end{array}$ & & & $\begin{array}{c}0.0139 \\
(0.13)\end{array}$ \\
\hline $\begin{array}{l}\text { Education of head of household } \\
- \text { completed primary school }\end{array}$ & $\begin{array}{l}0.0405 \\
(0.88)\end{array}$ & $\begin{array}{l}0.0441 \\
(0.94)\end{array}$ & $\begin{array}{c}0.0314 \\
(0.88)\end{array}$ & $\begin{array}{l}0.0419 \\
(0.91)\end{array}$ & $\begin{array}{l}0.045 \\
(0.97)\end{array}$ & $\begin{array}{l}0.0307 \\
(0.86)\end{array}$ \\
\hline $\begin{array}{l}\text { Education of head of household } \\
\text { - completed secondary school }\end{array}$ & 0.0123 & -0.007 & - & $\begin{array}{r}0.0109 \\
(0.18)\end{array}$ & -0.086 & - \\
\hline $\begin{array}{l}\text { Education of head of household } \\
\text { - completed higher education }\end{array}$ & $\begin{array}{l}(0.21) \\
0.156 \\
(1.36)\end{array}$ & $\begin{array}{l}(0.12) \\
0.136 \\
(1.17)\end{array}$ & - & $\begin{array}{l}(0.10) \\
0.153 \\
(1.34)\end{array}$ & $\begin{array}{l}(-0.14) \\
0.133 \\
(1.15)\end{array}$ & - \\
\hline $\begin{array}{l}\text { Initial education of head } \\
\text { - completed primary school }\end{array}$ & - & - & $\begin{array}{l}-0.0750 \\
(-1.30)\end{array}$ & & & $\begin{array}{l}-0.0756 \\
(-1.31)\end{array}$ \\
\hline Initial education of head & - & - & -0.0250 & & & -0.0269 \\
\hline - completed secondary school & - & - & $(-0.42)$ & & & $(-0.45)$ \\
\hline $\begin{array}{l}\text { Initial Education of head } \\
\text { - completed higher education }\end{array}$ & $\begin{array}{l}- \\
-\end{array}$ & - & $\begin{array}{c}-0.1025 \\
(-0.81)\end{array}$ & & & $\begin{array}{c}-0.1023 \\
(-0.81)\end{array}$ \\
\hline Farmer & $\begin{array}{c}-0.0202 \\
(-0.30)\end{array}$ & $\begin{array}{l}-0.0211 \\
(-0.31)\end{array}$ & $\begin{array}{l}0.005 \\
(0.53)\end{array}$ & $\begin{array}{l}-0.0220 \\
(-0.32)\end{array}$ & $\begin{array}{l}-0.023 \\
(-0.33)\end{array}$ & $\begin{array}{l}-0.004 \\
(0.44)\end{array}$ \\
\hline Agricultural wage labourer & $\begin{array}{l}0.162^{*} \\
(2.07)\end{array}$ & $\begin{array}{l}0.159^{*} \\
(2.01)\end{array}$ & - & $\begin{array}{l}0.157^{*} \\
(2.00)\end{array}$ & $\begin{array}{c}0.154+ \\
(1.94)\end{array}$ & $\begin{array}{l}- \\
-\end{array}$ \\
\hline Non-Agricultural wage labourer & 0.0541 & 0.0458 & - & 0.0487 & 0.0432 & - \\
\hline & $(0.77)$ & $(0.68)$ & - & $(0.69)$ & $(0.61)$ & - \\
\hline small business & 0.0563 & 0.0518 & - & 0.0542 & 0.0500 & - \\
\hline & $(0.82)$ & $(0.75)$ & - & $(0.79)$ & $(0.72)$ & - \\
\hline professionals & $\begin{array}{r}-0.0821 \\
(-1.07)\end{array}$ & $\begin{array}{l}-0.0874 \\
(-1.130)\end{array}$ & $\begin{array}{l}- \\
-\end{array}$ & $\begin{array}{c}-0.0864 \\
(-1.12)\end{array}$ & $\begin{array}{l}-0.0917 \\
(-1.18)\end{array}$ & $\begin{array}{l}- \\
-\end{array}$ \\
\hline others & $\begin{array}{l}0.0343 \\
(0.51)\end{array}$ & $\begin{array}{l}0.0238 \\
(0.350)\end{array}$ & $\begin{array}{l}- \\
-\end{array}$ & $\begin{array}{l}0.0304 \\
(0.45)\end{array}$ & $\begin{array}{l}0.0204 \\
(0.30)\end{array}$ & $\begin{array}{l}- \\
-\end{array}$ \\
\hline Farmer (Initial) & - & - & $\begin{array}{c}-0.1735+ \\
(-1.93)\end{array}$ & & & $\begin{array}{c}-0.17658 \\
(-1.96)\end{array}$ \\
\hline Agricultural wage labourer (Initial) & - & - & $\begin{array}{c}-0.2096^{\star} \\
(-1.97)\end{array}$ & & & $\begin{array}{l}-0.2013^{*} \\
(-1.89)+\end{array}$ \\
\hline Non-Agricultural wage labourer & - & - & -0.1548 & & & -0.1412 \\
\hline (Initial) & - & - & $(-1.50)$ & & & $(-1.36)$ \\
\hline small business (Initial) & - & - & $\begin{array}{l}-0.094 \\
(-1.06)\end{array}$ & & & $\begin{array}{l}-0.094 \\
(-1.05)\end{array}$ \\
\hline Professionals (Initial) & - & - & - & & & - \\
\hline & - & - & - & & & - \\
\hline Others (Initial) & - & - & $\begin{array}{l}-0.062 \\
(-0.58)\end{array}$ & & & $\begin{array}{l}-0.061 \\
(-0.57)\end{array}$ \\
\hline $\begin{array}{l}\text { Whether a household } \\
\text { has electricity or not }\end{array}$ & $\begin{array}{c}-0.00926 \\
(-0.29)\end{array}$ & $\begin{array}{c}-0.00930 \\
(-0.28)\end{array}$ & $\begin{array}{c}0.0039 \\
(0.08)\end{array}$ & $\begin{array}{c}-0.00884 \\
(-0.27)\end{array}$ & $\begin{array}{l}-0.009 \\
(-0.26)\end{array}$ & $\begin{array}{c}0.0068 \\
(0.14)\end{array}$ \\
\hline $\begin{array}{l}\text { Whether a household } \\
\text { has electricity or not (Initial) }\end{array}$ & - & - & $\begin{array}{l}0.0275 \\
(0.51)\end{array}$ & & & $\begin{array}{l}0.0279 \\
(0.52)\end{array}$ \\
\hline price of rice & -0.0778 & -0.0668 & 0.2213 & -0.0703 & -0.0617 & 0.2628 \\
\hline
\end{tabular}




\begin{tabular}{|c|c|c|c|c|c|c|}
\hline$(\log )$ & $(-0.38)$ & $(-0.32)$ & $(0.80)$ & $(-0.35)$ & $(-0.30)$ & $(0.95)$ \\
\hline price of potatoes & $0.260^{* *}$ & $0.260^{\star *}$ & $0.488^{* *}$ & $0.262^{* *}$ & $0.265^{\star \star}$ & $0.4968^{* *}$ \\
\hline$(\log )$ & (3.60) & $(3.60)$ & $(4.59)$ & (3.63) & (3.63) & $(4.66)$ \\
\hline price of milk & -0.0287 & -0.027 & -0.064 & -0.0271 & -0.026 & -0.063 \\
\hline$(\log )$ & $(-0.80)$ & $(-0.75)$ & $(-1.53)$ & $(-0.75)$ & $(-0.70)$ & $(-1.48)$ \\
\hline \multirow[t]{2}{*}{ Whether in 1998-9 } & - & - & - & - & - & - \\
\hline & - & - & - & - & - & - \\
\hline \multirow[t]{2}{*}{ Whether in1999-2000 } & $-0.220^{\star *}$ & $-0.224^{\star *}$ & - & $-0.228^{\star *}$ & $-0.232^{\star *}$ & - \\
\hline & $(-4.08)$ & $(-4.13)$ & - & $(-4.22)$ & $(-4.27)$ & - \\
\hline \multirow[t]{2}{*}{ Whether in 2004-5 } & $-0.275^{\star *}$ & $-0.279^{* *}$ & - & $-0.283^{\star \star}$ & $-0.288^{* *}$ & - \\
\hline & $(-4.71)$ & $(-4.72)$ & - & $(-4.85)$ & $(-4.85)$ & - \\
\hline \multirow[t]{2}{*}{ Constant } & $5.438^{\star *}$ & 5.399 & -0.375 & $5.415^{\star *}$ & 5.382 & -1.398 \\
\hline & $(8.44)$ & $(8.26)$ & $(4.93)$ & $(8.40)$ & $(8.23)$ & $(5.00)$ \\
\hline \multirow{4}{*}{$\begin{array}{l}\text { Observations } \\
\text { Number of hhid } \\
\text { Joint Significance }\end{array}$} & 5,991 & 5,812 & 2,174 & 5,991 & 5,812 & 2,174 \\
\hline & 2,634 & 2,519 & 1,087 & 2,634 & 2,519 & 1,087 \\
\hline & $F(20,3337)$ & $F(20,3273)$ & $F(24,2149)$ & $F(21,3336)$ & $F(21,3272)$ & $F(24,2148)$ \\
\hline & $8.196^{\star \star}$ & $7.88^{* *}$ & $20.71^{\star \star}$ & $7.92^{* *}$ & $7.64^{\star \star}$ & $19.77^{\star \star}$ \\
\hline
\end{tabular}

Table 1c Panel Data Models for Women's BMI

\begin{tabular}{|c|c|c|c|c|c|c|}
\hline \multirow[t]{2}{*}{ Dependent Variable } & \multicolumn{6}{|c|}{$\begin{array}{l}(15) \quad(16) \\
\text { Women's BMI }\end{array}$} \\
\hline & $\begin{array}{l}\text { Fixed- } \\
\text { Effects }\end{array}$ & $\begin{array}{l}\text { Fixed- } \\
\text { Effects } \\
\text { with } \\
\text { PSM }\end{array}$ & $\begin{array}{c}\text { Fixed- } \\
\text { Effects } \\
\text { :Control } \\
\text { for initial } \\
\text { Character- } \\
\text { istics } \\
\end{array}$ & $\begin{array}{l}\text { Fixed- } \\
\text { Effects }\end{array}$ & $\begin{array}{l}\text { Fixed- } \\
\text { Effects } \\
\text { with } \\
\text { PSM }\end{array}$ & $\begin{array}{c}\text { Fixed- } \\
\text { Effects } \\
\text { :Control } \\
\text { for initial } \\
\text { Character- } \\
\text { istics }\end{array}$ \\
\hline MFI loan amount (aggregate) & 0.0136 & 0.0130 & 0.0004 & - & - & - \\
\hline$(\log )$ & $(1.09)$ & $(1.04)$ & $(0.62)$ & - & - & - \\
\hline $\begin{array}{l}\text { MFI's productive loan amount } \\
(\log )\end{array}$ & $\begin{array}{l}- \\
-\end{array}$ & $\begin{array}{l}- \\
-\end{array}$ & - & $\begin{array}{c}0.00509 \\
(0.41)\end{array}$ & $\begin{array}{c}0.00555 \\
(0.45)\end{array}$ & $\begin{array}{c}0.00017 \\
(0.28)\end{array}$ \\
\hline $\begin{array}{l}\text { MFI's non-productive loan amount } \\
\text { (log) }\end{array}$ & - & $\begin{array}{l}- \\
-\end{array}$ & - & $\begin{array}{l}0.0442^{\star * 1} \\
(2.87)\end{array}$ & $\begin{array}{c}0.0443^{\star *} \\
(2.78)\end{array}$ & $\begin{array}{c}0.0017^{\star} \\
(2.30)\end{array}$ \\
\hline Age of the head of the hh & $\begin{array}{c}0.00382 \\
(0.40)\end{array}$ & $\begin{array}{c}0.00322 \\
(0.33)\end{array}$ & $\begin{array}{c}-0.00030 \\
(0.62)\end{array}$ & $\begin{array}{c}0.00319 \\
(0.34)\end{array}$ & $\begin{array}{c}0.00261 \\
(0.27)\end{array}$ & $\begin{array}{c}-0.00030 \\
(0.56)\end{array}$ \\
\hline Initial Age of the head of the hh & - & - & $\begin{array}{c}-0.0029 \\
(-1.60)\end{array}$ & - & - & $\begin{array}{c}-0.0027 \\
(-1.48)\end{array}$ \\
\hline Age_squared & $\begin{array}{l}-1.59 \mathrm{e}- \\
05 \\
(-0.71)\end{array}$ & $\begin{array}{l}-1.43 e- \\
05 \\
(-0.63)\end{array}$ & $\begin{array}{l}-1.55 \mathrm{e}- \\
05 \\
(-0.13)\end{array}$ & $\begin{array}{c}-1.43 e-05 \\
(-0.64)\end{array}$ & $\begin{array}{l}-1.28 \mathrm{e}- \\
05 \\
(-0.56)\end{array}$ & $\begin{array}{c}-1.76 \mathrm{e}- \\
07 \\
(-0.15)\end{array}$ \\
\hline Initial Age_squared & - & - & $\begin{array}{c}0.00002 \\
(1.17)\end{array}$ & - & - & $\begin{array}{c}0.00003 \\
(1.07)\end{array}$ \\
\hline Household size & $\begin{array}{c}-0.074^{* *} \\
(-2.66)\end{array}$ & $\begin{array}{c}-0.074^{\star *} \\
(-2.66)\end{array}$ & $\begin{array}{c}-0.0042^{\star *} \\
(-2.96)\end{array}$ & $\begin{array}{l}-0.074^{* *} \\
(-2.66)\end{array}$ & $\begin{array}{c}-0.074^{* *} \\
(-2.66)\end{array}$ & $\begin{array}{c}-0.0041^{* *} \\
(-2.94)\end{array}$ \\
\hline Initial Household size & - & - & $\begin{array}{c}0.0039^{*} \\
(2.16)\end{array}$ & - & - & $\begin{array}{c}0.0036^{*} \\
(2.01)\end{array}$ \\
\hline $\begin{array}{l}\text { Sex of head of household } \\
\text { (female or not) }\end{array}$ & $\begin{array}{l}-0.343 \\
(-1.11)\end{array}$ & $\begin{array}{l}-0.333 \\
(-1.06)\end{array}$ & $\begin{array}{c}-0.0278+ \\
(-1.81)\end{array}$ & $\begin{array}{l}-0.317 \\
(-1.03)\end{array}$ & $\begin{array}{l}-0.308 \\
(-0.98)\end{array}$ & $\begin{array}{c}-0.0270+ \\
(-1.76)\end{array}$ \\
\hline Initial Sex of head of household & - & - & $\begin{array}{c}-0.1320^{\star \star} \\
(-4.21)\end{array}$ & - & - & $\begin{array}{c}-0.1299^{* *} \\
(-4.15)\end{array}$ \\
\hline $\begin{array}{l}\text { Education of head of household } \\
\text { - completed primary school }\end{array}$ & $\begin{array}{l}0.284 \\
(1.42)\end{array}$ & $\begin{array}{l}-0.277 \\
(-1.37)\end{array}$ & $\begin{array}{l}0.002 \\
(0.32)\end{array}$ & $\begin{array}{l}-0.291 \\
(-1.46)\end{array}$ & $\begin{array}{l}-0.284 \\
(-1.41)\end{array}$ & $\begin{array}{l}0.002 \\
(0.26)\end{array}$ \\
\hline Education of head of household & -0.0322 & 0.018 & - & -0.0624 & 0.011 & - \\
\hline - completed secondary school & $(-0.12)$ & $(0.07)$ & - & $(-0.24)$ & $(0.04)$ & - \\
\hline Education of head of household & 0.498 & 0.354 & - & 0.438 & 0.294 & - \\
\hline - completed higher education & $(0.84)$ & $(0.59)$ & - & $(0.74)$ & $(0.49)$ & - \\
\hline Initial education of head & - & - & $0.023^{\star *}$ & - & - & $0.023^{* *}$ \\
\hline - completed primary school & - & - & $(2.45)$ & - & - & $(2.49)$ \\
\hline Initial education of head & - & - & 0.010 & - & - & 0.010 \\
\hline - completed secondary school & - & - & $(1.04)$ & - & - & $(1.04)$ \\
\hline Initial Education of head & - & - & 0.012 & - & - & 0.013 \\
\hline
\end{tabular}




\begin{tabular}{|c|c|c|c|c|c|c|}
\hline - completed higher education & - & - & $(0.56)$ & - & - & $(0.61)$ \\
\hline Farmer & $\begin{array}{l}-0.251 \\
(-0.90)\end{array}$ & $\begin{array}{l}-0.294 \\
(-1.03)\end{array}$ & $\begin{array}{c}-1.66 e-6 \\
(-0.00)\end{array}$ & $\begin{array}{l}-0.275 \\
(-0.98)\end{array}$ & $\begin{array}{l}-0.318 \\
(-1.12)\end{array}$ & $\begin{array}{c}-1.71 e-6 \\
(-0.11)\end{array}$ \\
\hline \multirow[t]{2}{*}{ Agricultural wage labourer } & -0.352 & -0.385 & - & -0.392 & -0.420 & - \\
\hline & $(-1.09)$ & $(-1.18)$ & - & $(-1.21)$ & $(-1.29)$ & - \\
\hline \multirow{2}{*}{ Non-Agricultural wage labourer } & -0.299 & -0.337 & - & -0.346 & -0.383 & - \\
\hline & $(-1.02)$ & $(-1.14)$ & - & $(-1.18)$ & $(-1.30)$ & - \\
\hline \multirow{2}{*}{ small business } & -0.297 & -0.329 & - & -0.324 & -0.354 & - \\
\hline & $(-1.03)$ & $(-1.14)$ & - & $(-1.13)$ & $(-1.23)$ & - \\
\hline \multirow[t]{2}{*}{ professionals } & $-0.691^{*}$ & $-0.703^{*}$ & - & $-0.739^{*}$ & $-0.749^{*}$ & - \\
\hline & $(-2.13)$ & $(-2.15)$ & - & $(-2.28)$ & $(-2.29)$ & - \\
\hline \multirow[t]{2}{*}{ others } & -0.246 & -0.281 & - & -0.288 & -0.321 & - \\
\hline & $(-0.88)$ & $(-0.100)$ & - & $(-1.03)$ & $(-0.14)$ & - \\
\hline \multirow[t]{2}{*}{ Farmer (Initial) } & - & - & 0.015 & - & - & 0.015 \\
\hline & - & - & $(0.97)$ & - & - & $(0.94)$ \\
\hline \multirow[t]{2}{*}{ Agricultural wage labourer (Initial) } & - & - & 0.031 & - & - & 0.030 \\
\hline & - & - & $(1.72)+$ & - & - & $(1.70)+$ \\
\hline \multirow{4}{*}{$\begin{array}{l}\text { Non-Agricultural wage labourer } \\
\text { (Initial) } \\
\text { small business (Initial) }\end{array}$} & - & - & 0.018 & - & - & 0.019 \\
\hline & - & - & $(1.02)$ & - & - & $(1.07)$ \\
\hline & - & - & 0.021 & - & - & 0.020 \\
\hline & - & - & $(1.32)$ & - & - & $(1.25)$ \\
\hline \multirow[t]{2}{*}{ Professionals (Initial) } & - & - & 0.037 & - & - & 0.036 \\
\hline & - & - & $(1.96)^{\star}$ & - & - & $(1.93)+$ \\
\hline \multirow[t]{2}{*}{ Others (Initial) } & - & - & - & - & - & - \\
\hline & - & - & - & - & - & - \\
\hline \multirow{3}{*}{$\begin{array}{l}\text { Whether a household } \\
\text { has electricity or not } \\
\text { Whether a household } \\
\text { has electricity or not (Initial) }\end{array}$} & 0.193 & 0.196 & $0.017^{*}$ & 0.189 & 0.191 & $0.016^{*}$ \\
\hline & $(1.35)$ & $(1.36)$ & $(2.14)$ & $(1.32)$ & $(1.34)$ & $(2.10)$ \\
\hline & $\begin{array}{l}- \\
-\end{array}$ & $\begin{array}{l}- \\
-\end{array}$ & $\begin{array}{l}0.016^{*} \\
(1.81)\end{array}$ & $\begin{array}{l}- \\
-\end{array}$ & $\begin{array}{l}- \\
-\end{array}$ & $\begin{array}{c}0.016+ \\
(1.76)\end{array}$ \\
\hline \multirow{2}{*}{$\begin{array}{l}\text { price of rice } \\
(\mathrm{log})\end{array}$} & -0.394 & -0.310 & 0.016 & -0.319 & -0.244 & -0.013 \\
\hline & $(-0.43)$ & $(-0.34)$ & $(1.81)+$ & $(-0.35)$ & $(-0.26)$ & $(0.30)$ \\
\hline \multirow{2}{*}{$\begin{array}{l}\text { price of potatoes } \\
\text { (log) }\end{array}$} & $-0.872^{*}$ & $-0.870^{*}$ & $-0.043^{*}$ & $-0.843^{*}$ & $-0.842^{*}$ & $-0.041^{*}$ \\
\hline & $(-2.50)$ & $(-2.25)$ & $(-2.51)$ & $(-2.42)$ & $(-2.41)$ & $(-2.43)$ \\
\hline \multirow{2}{*}{$\begin{array}{l}\text { price of milk } \\
(\log )\end{array}$} & $0.371^{* *}$ & $0.403^{* *}$ & $0.018^{* *}$ & $0.379^{\star *}$ & $0.411^{* *}$ & $0.019^{* *}$ \\
\hline & $(2.70)$ & $(2.89)$ & $(2.77)$ & $(2.76)$ & $(2.95)$ & $(2.80)$ \\
\hline \multirow[t]{2}{*}{ Whether in 1998-9 } & - & - & - & - & - & - \\
\hline & - & - & - & - & - & - \\
\hline \multirow[t]{2}{*}{ Whether in1999-2000 } & - & - & - & - & - & - \\
\hline & - & - & - & - & - & - \\
\hline \multirow[t]{2}{*}{ Whether in 2004-5 } & $1.965^{\star *}$ & $1.947^{* *}$ & $1.947^{\star *}$ & $1.915^{\star *}$ & $1.901^{\star *}$ & $1.947^{\star \star}$ \\
\hline & $(7.21)$ & $(7.11)^{\star \star}$ & $(7.11)^{\star \star}$ & $(6.99)$ & $(6.92)^{* *}$ & $(7.11)^{\star \star}$ \\
\hline \multirow[t]{2}{*}{ Constant } & 20.98 & 20.70 & 0.260 & 20.72 & 20.47 & 0.251 \\
\hline & $(7.18)$ & $(7.07)$ & $(5.17)$ & $(7.10)$ & $(7.07)$ & $(5.00)$ \\
\hline \multirow{4}{*}{$\begin{array}{l}\text { Observations } \\
\text { Number of hhid } \\
\text { Joint Significance }\end{array}$} & 3,988 & 3,881 & 1532 & 3,988 & 3,881 & 1532 \\
\hline & 2,444 & 2,349 & 766 & 2,444 & 2,349 & 766 \\
\hline & $F(19,1525)$ & $F(19,1513)$ & $F(24,1507)$ & $F(20,1524)$ & $F(20,1512)$ & $F(25,1506)$ \\
\hline & $28.82^{* \star}$ & $28.51^{* *}$ & $2.91^{* *}$ & $27.87^{\star \star}$ & $27.55^{\star \star}$ & $3.01^{* *}$ \\
\hline
\end{tabular}

Note 1. t-statistics in parentheses, ${ }^{* *} p<0.01,{ }^{*} p<0.05,+p<0.1$. 
Table 2 Effects of microfinance loans on growth of household income, food consumption and BMI (DID- Propensity Score Matching: Kernel Matching ${ }^{* 3,4, * 5}$ )

Case (a) Whether a household has access to MFI loans

\begin{tabular}{|c|c|c|c|c|c|}
\hline \multirow[b]{2}{*}{ Model } & \multicolumn{2}{|c|}{$\begin{array}{l}\text { Log per capita Household Income } \\
\text { (mean) } \\
\text { or First difference of Log per capita } \\
\text { Household Income }\end{array}$} & $\begin{array}{l}\text { Policy } \\
\text { Effect } \\
\text { (A-B) }\end{array}$ & \multirow[t]{2}{*}{ (t value) } & \multirow[t]{2}{*}{ No. of obs. } \\
\hline & $\begin{array}{c}\text { With access } \\
\text { to } \\
\text { MFI loans: A } \\
\end{array}$ & $\begin{array}{l}\text { Without access to } \\
\text { MFI loans: B }\end{array}$ & $\begin{array}{l}\text { ATT: } \\
\text { Average } \\
\text { treatment } \\
\text { effect } \\
\end{array}$ & & \\
\hline \multicolumn{6}{|c|}{ 1. Growth rate of household income per capita } \\
\hline $\begin{array}{l}1997-1998 \text { to } 1998-1999 \\
1998-1999 \text { to } 1999-2000 \\
1999-2000 \text { to } 2004-2005\end{array}$ & $\begin{array}{l}0.09883 \\
0.12951 \\
0.20182 \\
\end{array}$ & $\begin{array}{l}0.07449 \\
0.1007 \\
0.26111 \\
\end{array}$ & $\begin{array}{r}0.02434 \\
0.02881 \\
-0.05929 \\
\end{array}$ & $\begin{array}{l}(0.38) \\
(0.43) \\
(-1.14) \\
\end{array}$ & $\begin{array}{l}\text { Treat: } 140 \text {, Control: } \\
1081 \\
\text { Treat: } 151 \text {, Control: } \\
1270 \\
\text { Treat: } 424 \text {, Control: } \\
1250\end{array}$ \\
\hline \multicolumn{6}{|c|}{ 2. Growth rate of food consumption per capita } \\
\hline $\begin{array}{l}1997-1998 \text { to } 1999-2000 \\
1999-2000 \text { to } 2004-2005\end{array}$ & $\begin{array}{l}-0.31527 \\
0.36292 \\
\end{array}$ & $\begin{array}{l}-0.4055 \\
0.25854 \\
\end{array}$ & $\begin{array}{l}0.09026 \\
0.10438 \\
\end{array}$ & $\begin{array}{r}(1.49) \\
(2.25)^{\star} \\
\end{array}$ & $\begin{array}{l}\text { Treat: } 144 \text {, Control: } \\
1061 \\
\text { Treat: } 406 \text {, Control: } \\
1171 \\
\end{array}$ \\
\hline \multicolumn{6}{|c|}{ 3. Change of BMI of a woman (spouse of household head or household head) } \\
\hline $1997-1998$ to $2004-2005$ & -0.07358 & -0.0402 & -0.03341 & $(-0.27)$ & $\begin{array}{l}\text { Treat: } 102 \text {, Control: } \\
357\end{array}$ \\
\hline
\end{tabular}

Case (b) Whether a household has access to MFI productive loans

1. Growth rate of household income per capita

\begin{tabular}{|c|c|c|c|c|c|}
\hline $1997-1998$ to $1998-1999$ & 0.09876 & 0.06876 & 0.03 & $(0.14)$ & $\begin{array}{l}\text { Treat: } 163 \text {, Control: } \\
1180 \\
\text { Treat: 187, Control: }\end{array}$ \\
\hline $1998-1999$ to $1999-2000$ & 0.10625 & 0.08882 & 0.01743 & $(0.33)$ & $\begin{array}{l}1435 \\
\text { Treat: } 400 \text {, Control: }\end{array}$ \\
\hline $1999-2000$ to $2004-2005$ & 0.23062 & 0.25141 & -0.02079 & $(-0.45)$ & 1320 \\
\hline
\end{tabular}

2. Growth rate of food consumption per capita

\begin{tabular}{|c|c|c|c|c|c|}
\hline $1997-1998$ to $1999-2000$ & -0.31603 & -0.398 & 0.08197 & (1.04) & $\begin{array}{l}\text { Treat: } 113 \text {, Control: } \\
1092 \\
\text { Treat: } 404 \text { Control: }\end{array}$ \\
\hline $1999-2000$ & 0.32356 & 0.26423 & 0.05933 & (1.13) & 1351 \\
\hline
\end{tabular}

3. Change of BMI of a woman (spouse of household head or household head)

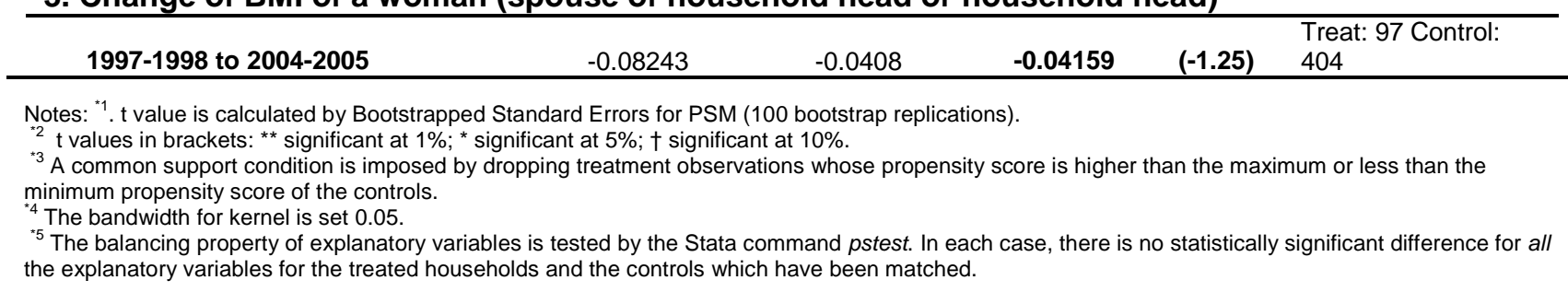




\section{References}

Ahlin, C. and Townsend, R. (2007) Using Repayment Data to Test Across Models of Joint Liability Lending, The Economic Journal, 117 (issue \#), pp. F11-F51.

Ahmed, S. (2007) Microfinance Programmes in Bangladesh: Experiences and Issues, in I. Simorangkir (ed.) Macroeconomic Stability towards high Growth and Employment: Proceedings on an International seminar held in Denpasar (Bali, Indonesia).

Armendáriz, B., and Morduch, J. (2005) The Economics of Microfinance (Cambridge, MA: The MIT Press).

Banerjee, A., Duflo, E., Glennerster, R. and Kinnan, C. (2010) The Miracle of Microfinance?

Evidence from a Randomised Evaluation, Department of Economics, Massachusetts Institute of Technology (MIT) Working Paper, June 2010.

Bateman, M., and Chang, H. (2009) The Microfinance Illusion, mimeo., Cambridge, Faculty of Economics, University of Cambridge.

Becker, S. and Ichino, A. (2002) Estimation of Average Treatment Effects based on Propensity Scores, The Stata Journal, 2(4), pp.358-377.

Besley, T., and Coate, S. (1995) Group lending, repayment incentives and social collateral, Journal of Development Economics, 46 (1), pp.1-18.

BBS (2008) Report On The Household Income and Expenditure Survey 2005 (Dhaka: Bangladesh Bureau of Statistics).

Chemin, M. (2008) The Benefits and Costs of Microfinance: Evidence from Bangladesh, Journal of Development Studies, 44 (4), pp.463-484.

Chen, S., Mu, R., and Ravallion, M. (2008) Are there lasting impacts of aid to poor areas ? Evidence from rural China, Policy Research Working Paper Series 4084 (Washington D.C., The World Bank). 
Dehejia, R. (2005) Practical Propensity Score Matching: a Reply to Smith and Todd, Journal of Econometrics, 125, pp.355-364.

Dehejia, R. and Wahba, S. (2002) Propensity Score Matching Methods for Nonexperimental Causal Studies, Review of Economics and Statistics, 84 (1), pp.151-161.

Ehrbeck, T. (2006) Optimizing capital supply in support of microfinance industry growth. Presentation at microfinance investor roundtable, Washington, DC, October 24-25. McKinsey\&Co.

Farashuddin, F. and Amin, N. (1998) Poverty Alleviation and Empowerment: An Impact Assessment Study of BRAC's RDP - Ten Qualitative Case Studies. Mimeo, (Dhaka: BRAC Research and Evaluation Division).

Foster, M. (2003). Propensity Score Matching: An Illustrative Analysis of Dose Response, Medical Care, 41(10), pp.1183-1192.

Greene, W. H. (2003). Econometric Analysis 5th Edition (Upper Saddle River, NJ: PrenticeHall).

Heckman, J., Ichimura, H. and Todd, P. (1997) Matching as an econometric evaluation estimator, Review of Economic Studies, 64(4), pp. 605-654.

Hulme, D. and Mosley, P. (1996) Finance against Poverty. Routledge, London.

Imai, K. S., Arun, T. and Annim, S. K. (2010) Microfinance and Household Poverty Reduction: New evidence from India, World Development, 38(12), pp.1760-1774.

Karlan, D. and Zinman, J. (2009) Expanding Microenterprise Credit Access: Using Randomized Supply Decisions to Estimate the Impacts in Manila. Working Paper. Yale University, Dartmouth College, and Innovations for Poverty Action.

Khandker, S. R. (2005) Microfinance and Poverty: Evidence Using Panel Data from Bangladesh, The World Bank Economic Review, 19(2), pp.263-286. 
Maddala, G. S. (1983) Limited dependent and qualitative variables in econometrics (Cambridge, Cambridge University Press).

Montgomery R., D. Bhattacharya and D. Hulme (1996) Credit for the Poor in Bangladesh: The BRAC Rural Development Programme and the Government Thana Resource Development and Employment Programme, in D. Hulme and P. Mosely, Finance against Poverty. Vols. I and 2 (London: Routledge).

Morduch, J. (1998) Does Microfinance Really Help the Poor: New Evidence from Flagship Programs in Bangladesh, Mimeo, Department of Economics and HIID, Harvard University and Hoover Institution, Stanford University.

Pitt, M., and Khandker, S. R. (1998) The Impact of Group-Based Credit on Poor Households in Bangladesh: Does the Gender of Participants Matter?, Journal of Political Economy, 106(5), pp.958-96.

Pitt, M. (2011a) 'Response to Roodman and Morduch's “The Impact of Microcredit on the Poor in Bangladesh: Revisiting the Evidence", mimeograph, Brown University, downloadable from http://www.pstc.brown.edu/ mp/papers/Pitt_response to_RM.pdf.

Pitt, M. (2011b) 'Overidentification Tests and Causality: A Second Response to Roodman and Morduch', mimeograph, Brown University, downloadable from http://www.pstc.brown.edu/ mp/papers/Overidentification.pdf.

PKSF (2006) MAPs on Microcredit Coverage in Upazilas of Bangladesh (Dhaka, Bangladesh, Palli Karma Sahayak Foundation).

Pollin, R. (2007) Microcredit: False Hopes and Real Possibilities. Foreign Policy Focus, available from http://www.fpif.org/fpiftxt/4323.

Ravallion, M. (2008) Evaluating Anti-Poverty Programme, Chapter 59 in Handbook of Development Economics, Volume 4, P. Schultz and J. Strauss (eds) (New York: North Holland) . 
Ravallion, M. and Chen, S. (2007) China's (uneven) progress against poverty, Journal of Development Economics, 82(1), pp. 1-42.

Roodman, D., and J. Morduch (2009) The Impact of Microcredit on the Poor in Bangladesh: Revisiting the Evidence, CGD Working Paper 174 (Washington, D.C.: Center for Global Development).

Rosenbaum, P. R., and Rubin, D. B. (1983) The Central Role of the Propensity Score in Observational Studies for Causal Effects, Biometrica, 70(1), pp.41-55.

Smith, J. A., and Todd, P. E. (2005) Does Matching Overcome LaLonde's Critique of Nonexperimental Estimators?, Journal of Econometrics, 125, pp.305-353.

Todd, P. E. (2008). 'Evaluating Social Programs with Endogenous Program Placement and Selection of the Treated', Chapter 60 in Handbook of Development Economics, Volume 4, P. Schultz and J. Strauss (eds) (New York, North-Holland).

Wood, G. and Sharif, I. (eds) (1997) Who needs credit? Poverty and finance in Bangladesh. (London, Zed Books).

Zaman, H. (1998) Who benefits and to what extent? An evaluation of BRAC's micro-credit program, University of Sussex, D.Phil thesis. 
Online Appendix 1: Descriptive Statistics for MFI participants and non-participants

\begin{tabular}{|c|c|c|c|c|c|c|c|c|c|c|c|c|c|}
\hline \multirow[t]{2}{*}{ Variable } & & \multicolumn{3}{|c|}{ With access to MFI } & \multicolumn{3}{|c|}{ Without access to MFI } & \multicolumn{3}{|c|}{$\begin{array}{l}\text { With access to MFI loan for } \\
\text { Productive Purposes }\end{array}$} & \multicolumn{3}{|c|}{$\begin{array}{l}\text { Without access to MFI laon for } \\
\text { Productive purposes }\end{array}$} \\
\hline & & Obs & Mean & Std. Dev. & Obs & Mean & Std. Dev. & Obs & Mean & Std. Dev. & Obs & Mean & Std. Dev. \\
\hline \multicolumn{14}{|c|}{ Age of Head of $\mathrm{HH}$ (age) } \\
\hline & Pooled & 5526 & 45.40 & 12.38 & 4954 & 47.32 & 15.50 & 3675 & 45.17 & 12.17 & 6805 & 46.93 & 14.82 \\
\hline & Round 1 & 1545 & 43.86 & 12.28 & 1078 & 45.42 & 14.77 & 1237 & 43.73 & 12.07 & 1386 & 45.19 & 14.42 \\
\hline & Round 2 & 1463 & 44.70 & 12.41 & 1170 & 46.62 & 14.49 & 948 & 44.53 & 12.11 & 1685 & 46.12 & 14.05 \\
\hline & Round 3 & 1327 & 45.85 & 12.47 & 1312 & 47.26 & 14.25 & 721 & 45.55 & 12.32 & 1918 & 46.93 & 13.77 \\
\hline & Round 4 & 1209 & 47.80 & 12.03 & 1420 & 49.43 & 17.56 & 778 & 47.82 & 11.79 & 1851 & 49.04 & 16.53 \\
\hline \multicolumn{14}{|c|}{ Sex of Head of HH (sex_hh) } \\
\hline & Pooled & 5528 & 0.95 & 0.22 & 4957 & 0.92 & 0.27 & 3676 & 0.95 & 0.21 & 6809 & 0.93 & 0.26 \\
\hline & Round 1 & 1545 & 0.96 & 0.20 & 1078 & 0.93 & 0.25 & 1237 & 0.96 & 0.20 & 1386 & 0.94 & 0.25 \\
\hline & Round 2 & 1463 & 0.95 & 0.21 & 1170 & 0.94 & 0.24 & 948 & 0.96 & 0.19 & 1685 & 0.94 & 0.24 \\
\hline & Round 3 & 1327 & 0.95 & 0.20 & 1312 & 0.93 & 0.24 & 721 & 0.96 & 0.18 & 1918 & 0.94 & 0.23 \\
\hline & Round 4 & 1209 & 0.93 & 0.29 & 1422 & 0.89 & 0.37 & 779 & 0.93 & 0.32 & 1852 & 0.90 & 0.35 \\
\hline \multicolumn{14}{|c|}{ Size of the HH (hh_size) } \\
\hline & Pooled & 5528 & 6.23 & 2.75 & 4957 & 6.27 & 3.16 & 3676 & 6.21 & 2.83 & 6809 & 6.27 & 3.02 \\
\hline & Round 1 & 1545 & 5.73 & 2.20 & 1078 & 5.52 & 2.44 & 1237 & 5.66 & 2.12 & 1386 & 5.62 & 2.45 \\
\hline & Round 2 & 1463 & 5.88 & 2.28 & 1170 & 5.88 & 2.60 & 948 & 5.82 & 2.26 & 1685 & 5.92 & 2.52 \\
\hline & Round 3 & 1327 & 6.08 & 2.34 & 1312 & 6.10 & 2.66 & 721 & 6.08 & 2.37 & 1918 & 6.09 & 2.55 \\
\hline & Round 4 & 1211 & 7.42 & 3.78 & 1423 & 7.32 & 4.08 & 779 & 7.66 & 4.05 & 1855 & 7.25 & 3.90 \\
\hline \multicolumn{14}{|c|}{ Dependency ratio (d_ratio) } \\
\hline & Pooled & 5526 & 0.98 & 0.70 & 4944 & 0.94 & 0.77 & 3676 & 0.97 & 0.69 & 6794 & 0.96 & 0.76 \\
\hline & Round 1 & 1545 & 0.98 & 0.68 & 1076 & 0.88 & 0.68 & 1237 & 0.98 & 0.68 & 1384 & 0.91 & 0.68 \\
\hline & Round 2 & 1463 & 0.99 & 0.67 & 1169 & 0.92 & 0.67 & 948 & 0.98 & 0.66 & 1684 & 0.94 & 0.68 \\
\hline & Round 3 & 1327 & 0.93 & 0.66 & 1311 & 0.88 & 0.65 & 721 & 0.93 & 0.66 & 1917 & 0.89 & 0.65 \\
\hline & Round 4 & 1209 & 1.02 & 0.81 & 1414 & 1.07 & 0.96 & 779 & 1.00 & 0.78 & 1844 & 1.07 & 0.95 \\
\hline \multicolumn{14}{|c|}{ Per capita Income (pcy) } \\
\hline & Pooled & 5528 & 638.15 & 1224.67 & 4957 & 823.70 & 2541.04 & 3676 & 664.04 & 1420.76 & 6809 & 759.24 & 2199.64 \\
\hline & Round 1 & 1545 & 541.48 & 485.61 & 1078 & 579.27 & 623.34 & 1237 & 552.64 & 506.98 & 1386 & 560.90 & 579.90 \\
\hline & Round 2 & 1463 & 577.15 & 647.30 & 1170 & 677.01 & 771.89 & 948 & 604.84 & 725.24 & 1685 & 630.84 & 696.55 \\
\hline & Round 3 & 1327 & 633.41 & 1349.08 & 1312 & 701.10 & 762.11 & 721 & 688.43 & 1785.16 & 1918 & 659.03 & 678.64 \\
\hline
\end{tabular}




\begin{tabular}{|c|c|c|c|c|c|c|c|c|c|c|c|c|c|}
\hline \multirow[t]{2}{*}{ Variable } & & \multicolumn{3}{|c|}{ With access to MFI } & \multicolumn{3}{|c|}{ Without access to MFI } & \multicolumn{3}{|c|}{$\begin{array}{l}\text { With access to MFI loan for } \\
\text { Productive Purposes }\end{array}$} & \multicolumn{3}{|c|}{$\begin{array}{l}\text { Without access to MFI laon for } \\
\text { Productive purposes }\end{array}$} \\
\hline & & Obs & Mean & Std. Dev. & Obs & Mean & Std. Dev. & Obs & Mean & Std. Dev. & Obs & Mean & Std. Dev. \\
\hline & Round 4 & 1211 & 826.00 & 2006.94 & 1423 & 1225.70 & 4578.39 & 779 & 875.71 & 2347.42 & 1855 & 1111.76 & 4053.84 \\
\hline \multicolumn{14}{|c|}{ Log of per capita income (Ipcy)) } \\
\hline & Pooled & 5528 & 6.17 & 0.71 & 4957 & 6.26 & 0.86 & 3676 & 6.19 & 0.71 & 6809 & 6.22 & 0.83 \\
\hline & Round 1 & 1545 & 6.05 & 0.70 & 1078 & 6.02 & 0.86 & 1237 & 6.07 & 0.70 & 1386 & 6.01 & 0.82 \\
\hline & Round 2 & 1448 & 6.10 & 0.76 & 1154 & 6.17 & 0.86 & 940 & 6.15 & 0.73 & 1662 & 6.12 & 0.84 \\
\hline & Round 3 & 1324 & 6.19 & 0.67 & 1302 & 6.24 & 0.80 & 720 & 6.24 & 0.66 & 1906 & 6.20 & 0.76 \\
\hline & Round 4 & 1211 & 6.38 & 0.66 & 1423 & 6.52 & 0.86 & 779 & 6.41 & 0.67 & 1855 & 6.48 & 0.82 \\
\hline \multicolumn{14}{|c|}{ Productive NGO loans (nl_prod) } \\
\hline & Pooled & 5528 & 8274.55 & 21739.83 & 4957 & 105.41 & 1822.62 & 3676 & 12585.50 & 25687.42 & 6809 & 0.00 & 0.00 \\
\hline & Round 1 & 1545 & 18505.53 & 37656.36 & 1078 & 200.92 & 3574.95 & 1237 & 23288.32 & 40838.83 & 1386 & 0.00 & 0.00 \\
\hline & Round 2 & 1463 & 4139.04 & 5639.96 & 1170 & 124.60 & 1067.35 & 948 & 6541.35 & 5845.09 & 1685 & 0.00 & 0.00 \\
\hline & Round 3 & 1327 & 3396.04 & 5156.92 & 1312 & 44.38 & 563.57 & 721 & 6331.19 & 5538.54 & 1918 & 0.00 & 0.00 \\
\hline & Round 4 & 1211 & 5488.87 & 9716.99 & 1423 & 71.63 & 810.70 & 779 & 8663.62 & 10945.31 & 1855 & 0.00 & 0.00 \\
\hline \multicolumn{14}{|c|}{ Non-productive NGO loans (nl_nprod) } \\
\hline & Pooled & 5528 & 2574.08 & 13832.51 & 4957 & 24.77 & 440.40 & 3676 & 2368.82 & 15820.98 & 6809 & 828.98 & 4693.11 \\
\hline & Round 1 & 1545 & 3267.84 & 17997.61 & 1078 & 11.64 & 307.84 & 1237 & 2620.46 & 17846.45 & 1386 & 1313.02 & 8999.78 \\
\hline & Round 2 & 1463 & 2357.83 & 4113.11 & 1170 & 35.25 & 427.70 & 948 & 2329.26 & 3814.28 & 1685 & 761.20 & 2798.14 \\
\hline & Round 3 & 1327 & 2328.31 & 19663.10 & 1312 & 7.69 & 220.83 & 721 & 2652.60 & 26393.51 & 1918 & 619.00 & 2560.33 \\
\hline & Round 4 & 1211 & 2238.30 & 4234.92 & 1423 & 41.40 & 638.83 & 779 & 1730.95 & 3664.54 & 1855 & 766.08 & 2794.69 \\
\hline \multicolumn{14}{|c|}{ Formal bank loans (fbl_tot) } \\
\hline & Pooled & 5528 & 376.26 & 3615.70 & 4957 & 848.57 & 20363.00 & 3676 & 385.46 & 4013.81 & 6809 & 715.14 & 17430.35 \\
\hline & Round 1 & 1545 & 194.22 & 1735.18 & 1078 & 470.96 & 4132.29 & 1237 & 188.41 & 1496.01 & 1386 & 414.64 & 3827.35 \\
\hline & Round 2 & 1463 & 396.77 & 2712.55 & 1170 & 772.65 & 4667.90 & 948 & 409.32 & 2621.24 & 1685 & 650.70 & 4205.15 \\
\hline & Round 3 & 1327 & 369.17 & 2516.35 & 1312 & 1562.59 & 38801.45 & 721 & 280.31 & 2294.18 & 1918 & 1218.93 & 32128.97 \\
\hline & Round 4 & 1211 & 596.65 & 6329.83 & 1423 & 585.94 & 5232.52 & 779 & 777.59 & 7698.03 & 1855 & 512.45 & 4718.14 \\
\hline \multicolumn{14}{|c|}{ Loans from friends and family (ffl_tot) } \\
\hline & Pooled & 5528 & 2258.52 & 10024.06 & 4957 & 2970.09 & 16144.27 & 3676 & 2138.78 & 10314.13 & 6809 & 2841.20 & 14625.54 \\
\hline & Round 1 & 1545 & 2515.75 & 11259.95 & 1078 & 3300.98 & 13033.71 & 1237 & 2513.46 & 11988.29 & 1386 & 3128.52 & 12053.55 \\
\hline & Round 2 & 1463 & 2571.42 & 9321.90 & 1170 & 3816.14 & 18025.69 & 948 & 2226.29 & 8493.35 & 1685 & 3629.88 & 16134.47 \\
\hline & Round 3 & 1327 & 2410.36 & 8732.30 & 1312 & 3938.79 & 22638.89 & 721 & 2381.82 & 8815.89 & 1918 & 3466.60 & 19353.00 \\
\hline & Round 4 & 1211 & 1516.01 & 10961.81 & 1423 & 1201.90 & 6336.88 & 779 & 1416.42 & 11523.49 & 1855 & 1316.87 & 7316.42 \\
\hline
\end{tabular}




\begin{tabular}{|c|c|c|c|c|c|c|c|c|c|c|c|c|c|}
\hline \multirow[t]{2}{*}{ Variable } & & \multicolumn{3}{|c|}{ With access to MFI } & \multicolumn{3}{|c|}{ Without access to MFI } & \multicolumn{3}{|c|}{$\begin{array}{l}\text { With access to MFI loan for } \\
\text { Productive Purposes }\end{array}$} & \multicolumn{3}{|c|}{$\begin{array}{l}\text { Without access to MFI laon for } \\
\text { Productive purposes }\end{array}$} \\
\hline & & Obs & Mean & Std. Dev. & Obs & Mean & Std. Dev. & Obs & Mean & Std. Dev. & Obs & Mean & Std. Dev. \\
\hline \multicolumn{14}{|c|}{ Loans from village money lenders (vml_tot) } \\
\hline & Pooled & 5528 & 486.51 & 4301.19 & 4957 & 818.06 & 7443.37 & 3676 & 624.81 & 5101.62 & 6809 & 653.22 & 6429.93 \\
\hline & Round 1 & 1545 & 561.08 & 5036.03 & 1078 & 737.06 & 7547.03 & 1237 & 608.50 & 5477.44 & 1386 & 655.63 & 6767.78 \\
\hline & Round 2 & 1463 & 408.36 & 2714.25 & 1170 & 1095.08 & 9792.01 & 948 & 515.43 & 3205.77 & 1685 & 824.95 & 8205.16 \\
\hline & Round 3 & 1327 & 351.79 & 3588.69 & 1312 & 613.10 & 4468.81 & 721 & 523.48 & 4514.05 & 1918 & 466.00 & 3864.57 \\
\hline & Round 4 & 1211 & 642.73 & 5420.97 & 1423 & 849.58 & 7281.99 & 779 & 896.08 & 6655.58 & 1855 & 695.01 & 6423.82 \\
\hline \multicolumn{14}{|c|}{ Distance to nearest Upzilla (dist_uz) } \\
\hline & Pooled & 5526 & 7.38 & 6.03 & 4956 & 7.71 & 6.28 & 3674 & 7.40 & 5.97 & 6808 & 7.61 & 6.25 \\
\hline & Round 1 & 1545 & 7.18 & 5.83 & 1078 & 8.06 & 6.58 & 1237 & 7.40 & 5.85 & 1386 & 7.67 & 6.43 \\
\hline & Round 2 & 1463 & 7.29 & 5.97 & 1170 & 7.83 & 6.38 & 948 & 7.36 & 5.98 & 1685 & 7.62 & 6.25 \\
\hline & Round 3 & 1327 & 7.28 & 5.98 & 1312 & 7.79 & 6.32 & 721 & 7.41 & 6.03 & 1918 & 7.57 & 6.20 \\
\hline & Round 4 & 1209 & 7.80 & 6.37 & 1422 & 7.28 & 5.92 & 777 & 7.41 & 6.10 & 1854 & 7.57 & 6.15 \\
\hline \multicolumn{14}{|c|}{ whether household has electricity or not (elec_hh) } \\
\hline & Pooled & 5503 & 0.27 & 0.44 & 4944 & 0.34 & 0.47 & 3662 & 0.28 & 0.45 & 6785 & 0.32 & 0.46 \\
\hline & Round 1 & 1537 & 0.25 & 0.43 & 1074 & 0.26 & 0.44 & 1231 & 0.24 & 0.43 & 1380 & 0.26 & 0.44 \\
\hline & Round 2 & 1455 & 1.77 & 0.42 & 1166 & 1.71 & 0.45 & 944 & 1.76 & 0.42 & 1677 & 1.73 & 0.44 \\
\hline & Round 3 & 1326 & 1.74 & 0.43 & 1312 & 1.66 & 0.47 & 721 & 1.73 & 0.44 & 1917 & 1.69 & 0.46 \\
\hline & Round 4 & 1203 & 1.63 & 0.48 & 1418 & 1.56 & 0.50 & 775 & 1.60 & 0.49 & 1846 & 1.59 & 0.49 \\
\hline
\end{tabular}




\section{Online Appendix 2: Results of logit model on the determinants of participation in microfinance (or access to productive loans)}

In the following table, we present the results of logit model for all the rounds as well as each round. To briefly summarise the results, the coefficient estimate of age of head of the household is positive and significant in all cases, but the statistically significant and negative coefficient estimate of 'age squared' suggests a non-linear effect of age of the head. In the participation equation, the coefficient estimate for female head of the household is positive and significant in a majority of the cases, given that microfinance targets women. The coefficient estimate of distance from the nearest Upzilla (a business hub) is negative and significant only in the first column. A negative sign indicates that a household living closer to the nearest town with Upzilla is more likely to access MFI loans than those who live far away. This makes sense because Upzilla provides banking, marketing and other essential services for micro businesses and enterprises to market their products. The number of village money lenders is negative and statistically significant in a few cases.

The coefficient estimates of the education dummies are all negative and significant except for most of the cases of primary education. This means the reference category, i.e., illiterate households, are more likely to have a member participating in microfinance programmes. Coefficient estimates of different occupational categories reveal that a household whose head's occupation is non-agricultural wage labourer or small business is more likely to have a member participating in microfinance programmes. This makes sense as these two categories form the core clientele of MFIs. 


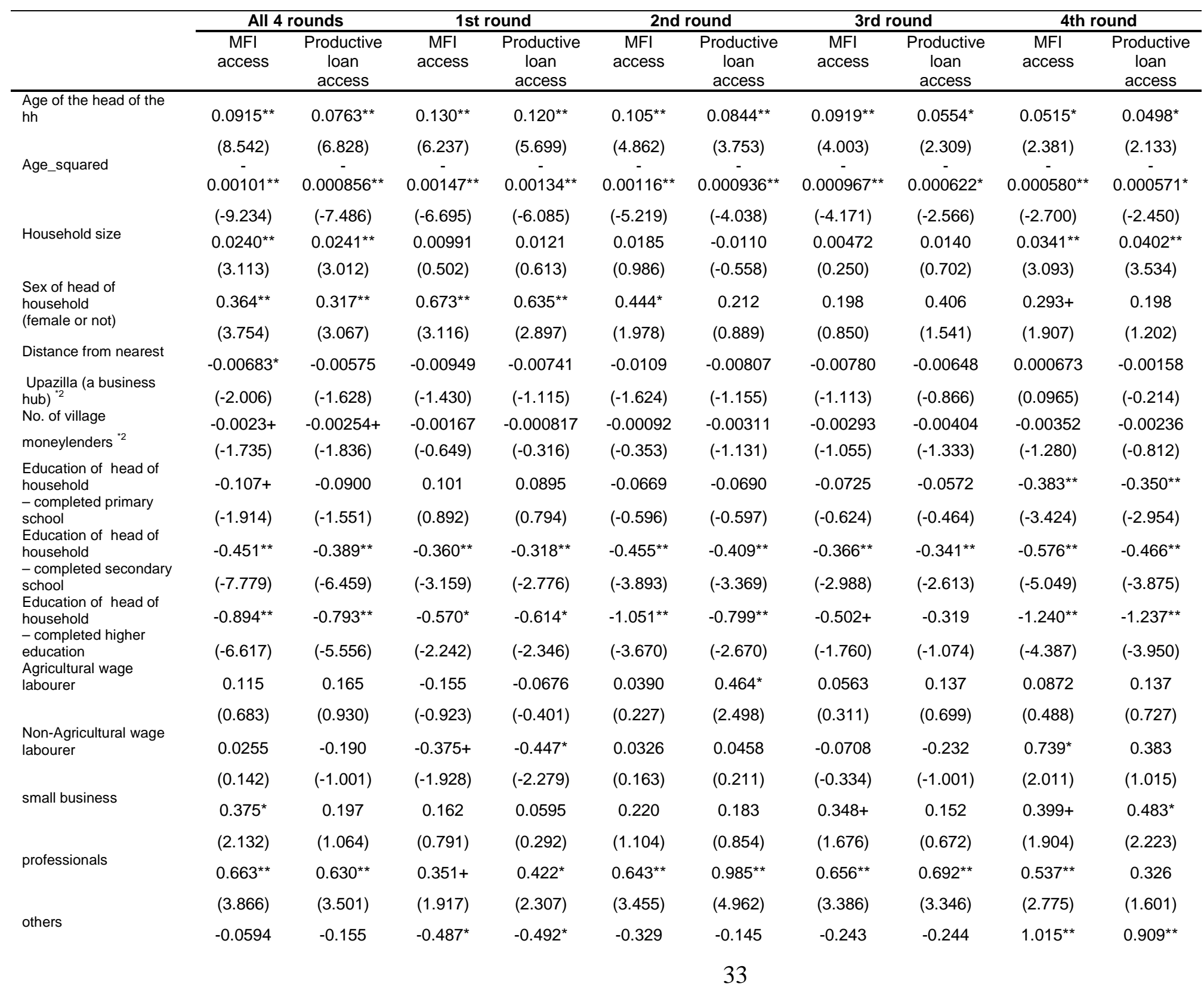




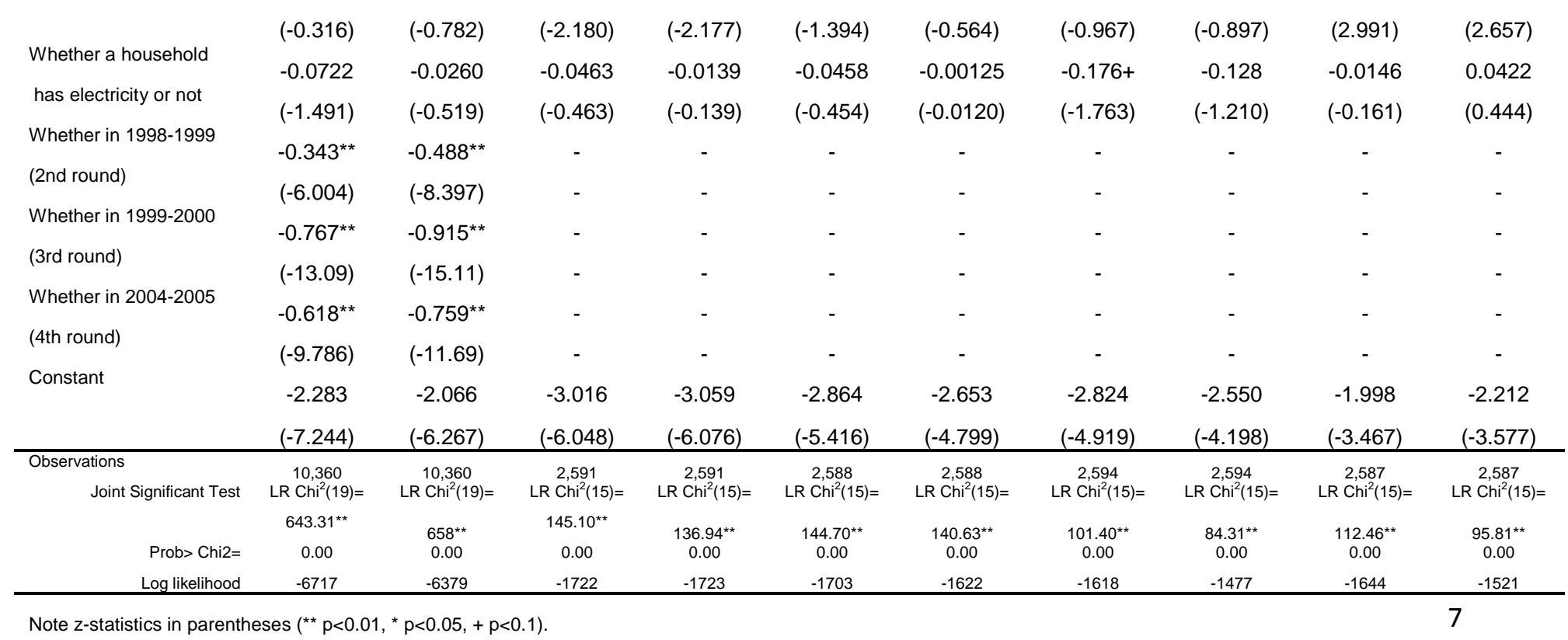




\section{Online Appendix 3: Effects of microfinance loans on level of household income, food

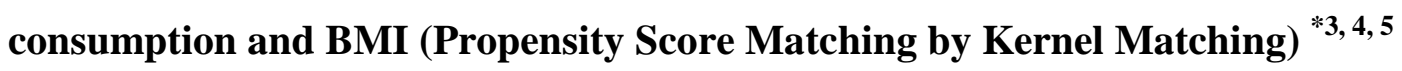

The following table presents the results of PSM based on cross-sectional data. Case (a) is the case of access to MFI's general loans and Case (b) is of access to MFI's productive loans. The results for all four rounds are shown for log household income per capita, while those for food consumption are only for the first, the third and the last rounds and those for women's BMI for the third and the last rounds due to the problem of missing observations. In case of income, a similar pattern has been observed for both access to MFI's general loans and productive loans. That is, positive policy effects in the first three rounds (where a statistically significant and positive effect is found only in 1998-9) turned negative and significant in the last round in 2004-5. As an extension, we have repeated PSM for four different income groups: $0-25 \%, 25-50 \%, 50-75 \%$ and $75 \%-100 \%$. In 1998-9, we have found a positive and significant policy effect only for the poorest group of households (0-25\%), which further supports the policy effectiveness of microfinance programmes. If we disaggregate PSM by income groups for the last round, we find for both general and productive loans a positive and significant average treatment effect on income for the poor group (0-25\%) and a negative and significant average treatment effect on the group with the income range of $75-100 \%$. This implies that microfinance programmes continued to have a poverty-reducing effect for the poorest in 2004-5. On food consumption, the effect of access to general loans is positive and non-significant, while that of access to productive loans is positive and significant in 1997-8 and in 1999-2000. The effects of MFI loans on women's BMI are insignificant in the first and the last rounds. All these results have to be interpreted with caution because of the limitations of PSM for cross-sectional data which we discussed in Section IV. 


\begin{tabular}{|c|c|c|c|c|c|c|}
\hline \multirow[b]{2}{*}{ Model } & \multicolumn{2}{|c|}{$\begin{array}{l}\text { Log per capita Household Income } \\
\text { (mean) } \\
\text { or First difference of Log per capita } \\
\text { Household Income }\end{array}$} & \multirow[t]{2}{*}{$\begin{array}{l}\text { Policy } \\
\text { Effect } \\
\text { (A-B) }\end{array}$} & \multirow[t]{2}{*}{$\begin{array}{c}\% \\
\text { change }\end{array}$} & \multirow[t]{2}{*}{ (t value) } & \multirow[t]{2}{*}{ No. of obs. } \\
\hline & $\begin{array}{c}\text { With access } \\
\text { to } \\
\text { MFI loans: A } \\
\end{array}$ & $\begin{array}{c}\text { Without access to } \\
\text { MFI loans: B }\end{array}$ & & & & \\
\hline \multicolumn{7}{|c|}{ 1. Effect on log household income per capita (level) } \\
\hline 1997-1998 & 6.0636 & 6.0173 & 0.0463 & 4.74 & $(1.46)$ & \multirow{4}{*}{$\begin{array}{l}\text { Treat: } 1344, \\
\text { Control:1247 } \\
\text { Treat: } 1127 \text {, Control: } \\
1430 \\
\text { Treat: } 890 \text {, Control: } \\
1692 \\
\text { Treat: } 949 \text {, Control: } \\
1638\end{array}$} \\
\hline 1998-1999 & 6.12803 & 6.0682 & 0.05983 & 6.17 & $(1.96)^{\star}$ & \\
\hline 1999-2000 & 6.21238 & 6.1797 & 0.03268 & 3.32 & $(1.33)$ & \\
\hline 2004-2005 & 6.39602 & 6.45781 & -0.06179 & -5.99 & $(-2.06)^{\star}$ & \\
\hline \multicolumn{7}{|c|}{ 2. Effect on log household food consumption per capita (level) } \\
\hline 1997-1998 & 5.8878 & 5.8752 & 0.0126 & 1.27 & $(0.66)$ & \multirow{3}{*}{$\begin{array}{l}\text { Treat: } 1344, \text { Control: } \\
1247 \\
\text { Treat: } 875 \text {, Control: } \\
1660 \\
\text { Treat: } 930 \text {, Control: } \\
1567\end{array}$} \\
\hline 1999-2000 & 5.4996 & 5.4682 & 0.0314 & 3.19 & $(1.45)$ & \\
\hline 2004-2005 & 5.79482 & 5.76009 & 0.03473 & 3.53 & $(0.74)$ & \\
\hline \multicolumn{7}{|c|}{ 3. Effect on BMI of a woman (level) (spouse of household head or household head) } \\
\hline 1997-1998 & 18.371 & 18.501 & -0.13 & -0.70 & $(-1.07)$ & $\begin{array}{l}\text { Treat: } 1205, \text { Control: } \\
1057 \\
\text { Treat: } 788, \text { Control: }\end{array}$ \\
\hline 2004-2005 & 19.7805 & 19.9727 & -0.1922 & -0.96 & $(-1.11)$ & 1212 \\
\hline \multicolumn{7}{|c|}{ Case (b) Whether a household has access to MFI productive loans } \\
\hline \multicolumn{7}{|c|}{ 1. Effect on log household income per capita (level) } \\
\hline 1997-1998 & 6.0755 & 6.018 & 0.0575 & 5.92 & $(1.62)$ & \multirow{4}{*}{$\begin{array}{l}\text { Treat: } 1223 \text {, Control: } \\
1368 \\
\text { Treat: } 926, \text { Control: } \\
1631 \\
\text { Treat: } 706, \text { Control: } \\
1876 \\
\text { Treat: } 763 \text {, Control: } \\
1824\end{array}$} \\
\hline 1998-1999 & 6.15386 & 6.06382 & 0.09004 & 9.42 & $(2.10)^{\star}$ & \\
\hline $1999-2000$ & 6.24694 & 6.17971 & 0.06723 & 6.95 & $(1.18)$ & \\
\hline 2004-2005 & 6.41003 & 6.45213 & -0.0421 & -4.12 & $(-2.06)^{\star}$ & \\
\hline \multicolumn{7}{|c|}{ 2. Effect on log household food consumption per capita (level) } \\
\hline 1997-1998 & 5.89383 & 5.87255 & 0.02128 & 2.15 & $(2.40)^{\star}$ & \multirow{3}{*}{$\begin{array}{l}\text { Treat: } 1223 \text {, Control: } \\
1368 \\
\text { Treat: } 694 \text {, Control: } \\
1541 \\
\text { Treat: } 747, \text { Control: } \\
1750\end{array}$} \\
\hline 1999-2000 & 5.51633 & 5.46927 & 0.04706 & 4.82 & $(2.09)^{\star}$ & \\
\hline 2004-2005 & 5.81154 & 5.77621 & 0.03533 & 3.60 & $(0.74)$ & \\
\hline \multicolumn{7}{|c|}{ 3. Effect on BMI of a woman (level) (spouse of household head or household head) } \\
\hline 1997-1998 & 18.404 & 18.472 & -0.068 & -0.37 & $(-0.63)$ & $\begin{array}{l}\text { Treat: } 1099 \text {, Control: } \\
1163 \\
\text { Treat: } 633 \text {, Control: }\end{array}$ \\
\hline 2004-2005 & 19.8144 & 19.984 & -0.1696 & -0.85 & $(-0.92)$ & 1367 \\
\hline \multicolumn{7}{|c|}{$\begin{array}{l}\text { Notes: }{ }^{*} \text {. } t \text { value is calculated by Bootstrapped } \\
\text { Standard Errors for PSM ( } 100 \text { bootstrap } \\
\text { replications) } \\
{ }_{* 2} t \text { values in brackets: }{ }^{* *} \text { significant at } 1 \% ;{ }^{*} \text { significant at } 5 \% ; \dagger \text { significant at } 10 \% \text {. } \\
{ }^{* 3} \text { A common support condition is imposed by dropping treatment observations whose propensity score is higher than the maximum or less than the minimum } \\
\text { propensity score of the controls. } \\
{ }^{4} \text { The bandwidth for kernel is set } 0.05 \text {. } \\
{ }_{5}^{5} \text { The balancing property of explanatory variables is tested by the Stata command pstest. In each case, there is no statistically significant difference for all the } \\
\text { explanatory variables for the treated households and the controls which have been matched. }\end{array}$} \\
\hline
\end{tabular}




\section{Endnotes}

${ }^{1}$ Joint liability payment may not be imposed on the group, for example, in case of lending by Grameen Bank, but repayment performance of the group is closely monitored by the communities and the Bank. To maintain reputations in the community, a member has an incentive to build skills and work hard to keep repaying the installments.

${ }^{2}$ Results of propensity score matching (PSM) are reported in Online Appendix 3 bearing in mind the limitations.

${ }^{3}$ Roodman and Morduch (2009) are critical of Pitt and Khandker (1998) but Pitt (2011 a, b) provides a valid response to the critique.

${ }^{4}$ While this distinction is important in evaluating microfinance programmes (e.g. Imai et al., 2010), the results will have to be interpreted with caution because the funds are fungible, that is, there might be some cases where the borrowers use loans for a purpose different from the one initially specified by the lenders.

${ }^{5}$ The evidence for other countries is inconclusive e.g. Banerjee, Duflo, Glennerster and Kinnan (2010) for slum dwellers in Hyderabad, India; Karlan and Zinman (2009) for the Philippines; and Imai et al. (2010) for India in 2000.

${ }^{6} \mathrm{BMI}$ may respond reasonably quickly to a loan-induced increase in income, but we include it as a measure on non-monetary poverty to capture female wellbeing.

${ }^{7} \mathrm{We}$ conducted fixed-effects IV estimation as a robustness check and the results (available on request) are broadly consistent with those reported here.

${ }^{8}$ As PSM for cross-section data is based only on observables and cannot control for unobservables, DID-PSM is considered in the next sub-section.

${ }^{9}$ We have used the Stata command pscore to identify common support in estimating fixed-effects PSM model. In carrying out DID-PSM as well as PSM, we have applied different commands, psmatch 2 and pstest and thus have obtained different ranges of common support for each round.

${ }^{10}$ See Becker and Ichino (2002) for technical details of PSM. We adopt Kernel Matching for PSM and DID-PSM where all treated are matched with a weighted average of all controls with weights that are inversely proportional to the distance between the propensity scores of treated and controls. We also tried Nearest Neighbour Matching to take each treated unit and search for the control unit with the closest propensity score and have obtained broadly similar results. To save the space, only the results based on Kernel Matching are presented.

${ }^{11}$ A summary of policy effects derived by PSM applied for each cross-sectional component of the panel is in Online Appendix 3. 